\title{
Electrical, Thermal, and Mechanical Characterization of Hot Coined Carbon Fiber Reinforced Pure Aluminium Composites
}

\author{
Mostafa Eid ${ }^{1} \cdot$ Saleh Kaytbay ${ }^{1} \cdot$ Ahmed El-Assal $^{1} \cdot$ Omayma Elkady ${ }^{2} \mathbb{C}$
}

Received: 17 November 2021 / Accepted: 17 January 2022 / Published online: 2 March 2022

(c) The Author(s) 2022, corrected publication 2022

\begin{abstract}
Poor interfacial structure and severe agglomerations of carbon fiber (CF) are significant problems that face carbon fiber reinforced aluminium (CF/Al) composites. Thus, $\mathrm{CF}$ was surface modified with nano copper particles $(\mathrm{Cu})$ to overcome these problems. Two groups of CF/Al composites (uncoated and coated) at different weight percentages of reinforcement $(0,5,10,15$, and 20$)$ were fabricated using the planetary ball milling method and then uniaxially hot coined at $550{ }^{\circ} \mathrm{C}$ under $700 \mathrm{MPa}$. The results showed that $\mathrm{CF}$ refined the crystallite size of the $\mathrm{Al}$ matrix, and no $\mathrm{Al}_{4} \mathrm{C}_{3}$ or $\mathrm{Al}_{2} \mathrm{Cu}$ were detected in XRD patterns. The density and thermal expansion of composites reduced with increasing CF percentage in all samples. The electrical and thermal conductivities are improved up to $10 \mathrm{wt} \%$ of uncoated reinforcement and $15 \mathrm{wt} \%$ of coated one. The mechanical test results revealed that by increasing $\mathrm{CF}$, the compressive strength of composites decreased while the wear properties improved for both groups. $\mathrm{Cu}$ deposition on $\mathrm{CF}$ improved the bonding between reinforcement and matrix, producing composites with better interfacial bonding, fewer agglomerations and porosity, and higher values of the properties of the composites.
\end{abstract}

Keywords CF/Al composites $\cdot$ Surface modification $\cdot$ Ball milling $\cdot$ Hot coining technique $\cdot$ Thermal and mechanical properties

\section{Introduction}

Recently, efficient thermal management has become tremendously important for electronic devices to avoid overheating generated in electronic package applications, inducing efficiency degradation and systems failure. Therefore, developing materials characterized by high thermal conductivity and a low coefficient of thermal expansion (CTE) is essential to satisfy the electronic device thermal dissipation requirements [1-4].On the other side, the world interest in high strength, lightweight and anti-corrosion materials which are used for aerospace, vehicles and defence applications has tremendously increased because of their potential to

Omayma Elkady

o.alkady68@gmail.com

1 Department of Mechanical Engineering, Benha Faculty of Engineering, Benha University, Banha, Egypt

2 Powder Technology Division, Manufacturing Technology Department, Central Metallurgical Research and Development Institute CMRDI, Cairo Governorate, Egypt enhance energy efficiency and reduce fuel consumption and $\mathrm{CO}_{2}$ emissions.

Aluminium matrix composites (AMCs) are considered promising materials used in many industrial applications. Although Al element has unique features such as low density, low melting point, abundant, good formability, and a high potential for recycling, its relatively high CTE, low mechanical properties and low wear resistance at high temperatures hinder its use in thermal and mechanical applications. So the integration of ceramic reinforcements into the Al matrix is an efficient way to overcome these limitations [5-7]. CF is an excellent material to reinforce $\mathrm{Al}$ and its alloys due to its superb properties. CF possesses ultra-high thermal conductivity $\left(800 \mathrm{Wm}^{-1} / \mathrm{K}^{-1}\right)$, remarkable CTE (10-15 ppm/K), high workability, low density (1.75-2.25 $\mathrm{g} / \mathrm{Cm}^{-3}$ ), high tensile strength (2-7 GPa), high young modulus (200-900 GPa) and low-cost material [8]. In addition, CF has not only high mechanical properties but also improves tribological properties of $\mathrm{AMC}_{S}[9,10]$. Thus, CF/Al composites are preferred for thermal management materials and transport sectors $[8,11-13]$. For example, CF / Al composites have been used to fabricate Hubble Space Telescope 
[14]. Moreover, they are also used to reduce the thermal stress on electronic packages $[15,16]$. Despite the excellent properties of $\mathrm{CF} / \mathrm{Al}$ composites, some challenges hinder the progress of the manufacturing of these composites.

Low wettability and excessive harmful reactions are the main drawbacks that encountered the fabrication of highperformance $\mathrm{CF} / \mathrm{Al}$ composites and deteriorated their thermal and mechanical properties $[11,17]$. The contact angle between $\mathrm{Al}$ and $\mathrm{CF}$ is $140^{\circ}$ [18].This makes it easy to form pores and agglomerations at the interface due to their significant difference in density and melting points [7, 19]. The metallic coating is usually applied on the CF surface to improve not only the interfacial bonding and wettability but also the properties of composites [20-22]. The electroless coating is the most common technique used in the coating process owing to its simple, few tools used, and uniform coating layers can be obtained [23, 24]. Electroless $\mathrm{Cu}$ or nickel (Ni) metals are commonly adapted for CF materials [25-28]. For example, Jiang et al.[29] proved that graphite coating with $\mathrm{Cu}$ and $\mathrm{Ni}$ could enhance the interfacial structure between two constituents in graphite flakes/Al composites.

On the other side, $\mathrm{CF}$ reacts with $\mathrm{Al}$ at temperatures above $500{ }^{\circ} \mathrm{C}$ to produce $\mathrm{Al}_{4} \mathrm{C}_{3}$ which is an undesirable intermediate phase, and this reaction increases with an increase in temperatures [30,31]. This interfacial product negatively affects the thermal and mechanical properties of $\mathrm{CF} / \mathrm{Al}$ composites [32, 33]. For controlling the harmful reactions, suitable processing methods and processing parameters (time-temperature-pressure) should be chosen. $\mathrm{CF} / \mathrm{Al}$ composites are manufactured by either liquid state or solidstate techniques [34]. Although liquid-based processes are cost-effective and simple, they require elevated temperature and high-pressure conditions. The segregation of reinforcements and intermetallic phase in these techniques impeded their widespread use $[35,36]$. The hot coining technique is usually recommended for $\mathrm{CF} / \mathrm{Al}$ fabrication because it restricts excessive interfacial reactions owing to their relatively low sintering temperature and uniform fiber distribution in the matrix $[33,35,37,38]$. Moreover, near net shape can be produced, depending on the appropriate die design. Also, it is a rapid consolidating technique that eliminates the possibility of matrix grain growth, resulting in smaller grain size in composites and subsequently better composite characteristics according to the Hall Petch mechanism. Therefore, it is a motivating point to address fabricating $\mathrm{CF} /$ $\mathrm{Al}$ composites using a hot coining technique with remarkable thermal and mechanical properties.

To our knowledge, many studies have paid attention to the effect of Ni surface modification on CF/Al composites fabricated by solid-state techniques [22, 39, 40]. Others studied the effect of $\mathrm{Cu}$ surface modification on the properties of composites. For example, Urena et al.[41] investigated the interfacial mechanical properties using the nanoindentation technique of $\mathrm{Cu}$ coated $2 \mathrm{wt} \%$ CF/AA6061 composites fabricated via cold compaction process. The results from their work revealed that nanoindentation is an effective method for measuring the hardness and elastic modulus of composites. They also reported that the hardness and stiffness are increased by electroless copper plating. The effect of $\mathrm{Cu}$ coating on $\mathrm{CF}$ in wear properties of $2 \mathrm{wt} \% \mathrm{CF} / \mathrm{AA} 6061$ composites prepared by melting tests of cold compressed powder pellets was also investigated in the previous work [42]. It was observed from this work that the wetting of the deposited coatings favored the distribution of reinforcement in the matrix and lowered the risk of reinforcement being dislodged from the composites.

From the previous literature, $\mathrm{Cu}$ surface modification was performed at a low weight percentage of $\mathrm{CF}$ in $\mathrm{Al}$ alloys and these composites were manufactured by traditional cold compaction technique. However, investigations associated with $\mathrm{Cu}$ surface modification at different high weight percentages of $\mathrm{CF}$ in pure $\mathrm{Al}$ and using the novel hot coining process to fabricate $\mathrm{CF} / \mathrm{Al}$ composites have not been studied yet. Thus, this research aimed to fabricate uncoated and nano $\mathrm{Cu}$-coated $\mathrm{CF} / \mathrm{Al}$ composites with high contents of reinforcement by the hot-coining method to study the influence of surface modification and reinforcement weight percentages on the microstructure, density, electrical and thermal conductivities (TC), coefficient of thermal expansion (CTE), hardness, compressive strength, and wear properties of $\mathrm{CF} /$ $\mathrm{Al}$ composites. This study is significant because it presents a novel way to produce $\mathrm{CF} / \mathrm{Al}$ composites with low interfacial reactions and remarkable properties.

\section{Experimental Work}

\subsection{Materials}

Commercially available $\mathrm{Al}$ powder with an average diameter of $60 \mu \mathrm{m}$ was used as a matrix, while CF $(7 \mu \mathrm{m}$ in diameter and $100 \mu \mathrm{m}$ in length) was supplied from Easy Composites Ltd and used as a reinforcement material. The characteristics of the $\mathrm{CF}$ used are shown in Table 1. Ammonium hydroxide $\left(\mathrm{NH}_{4} \mathrm{OH}\right)$, Silver nitrate $\left(\mathrm{Ag} \mathrm{NO}_{3}\right)$, Formaldehyde

Table 1 The properties of CF

\begin{tabular}{ll}
\hline Parameter & Value \\
\hline Density & $1.8 \mathrm{gm} / \mathrm{Cm}^{3}$ \\
Hardness & $2.9 \mathrm{GPa}$ \\
Melting point & $3500^{\circ} \mathrm{C}$ \\
Purity & $100 \%$ \\
Tensile Strength & $3150 \mathrm{MPa}$ \\
Tensile Modulus & $200 \mathrm{GPa}$ \\
\hline
\end{tabular}


$\left(\mathrm{CH}_{2} \mathrm{O}, 37 \%\right)$, Potassium sodium tartrate, which is called Rochell salt $\left(\mathrm{KNa} \mathrm{C}_{4} \mathrm{H}_{4} \mathrm{O}_{6} \cdot 4 \mathrm{H}_{2} \mathrm{O}\right)$, and copper sulphate pentahydrate $\left(\mathrm{CuSO}_{4} .5 \mathrm{H}_{2} \mathrm{O}\right)$ were used as a bath for nano $\mathrm{Cu}$ deposition and were purchased from ElNasr Chemical Co. LTD, Egypt.

\subsection{Electroless Nano Copper Coating of CF}

Before electroless $\mathrm{Cu}$ coating of reinforcement, $\mathrm{CF}$ was pretreated by two subsequent steps: sensitization and activation. Sensitization is an essential process to remove any impurities on $\mathrm{CF}$ surfaces and ensure.

a perfect metal deposition. This can be performed by immersing $\mathrm{CF}$ in sodium hydroxide solution using an ultrasonic cleaner for $1 \mathrm{~h}$. After that, the sensitized CF was passed into the activation solution $(0.017 \mathrm{~mol} / \mathrm{L} \mathrm{Ag}$ $\mathrm{NO}_{3}, 300 \mathrm{ml} / \mathrm{LCH}_{2} \mathrm{O}$ ) and magnetically stirred in the bath for $15 \mathrm{~min}$. The $\mathrm{CF}$ activation process aims to create craterlike impressions to rough ceramic reinforcement for a successful coating process. Finally, activated $\mathrm{CF}$ was added to a bath which contains $\left(0.14 \mathrm{~mol} / \mathrm{L} \mathrm{CuSO}_{4} .5 \mathrm{H}_{2} \mathrm{O}, 0.6 . \mathrm{mol} / \mathrm{L}\right.$ $\left.\mathrm{KNa} \mathrm{C}_{4} \mathrm{H}_{4} \mathrm{O}_{6} .4 \mathrm{H}_{2} \mathrm{O}, 1.25 \mathrm{~mol} / \mathrm{L} \mathrm{NaOH}, 200 \mathrm{ml} / \mathrm{LCH}_{2} \mathrm{O}\right)$. The $\mathrm{pH}$ of the solution was adjusted to about 12 using an alkaline solution. As soon as the solution had become transparent and the $\mathrm{CF}$ appeared in bright red, the reaction ended. CF was washed with acetone and water several times between each step and finally dried at $90{ }^{\circ} \mathrm{C}$ for $1 \mathrm{~h}$ in a muffle furnace. Coated $\mathrm{CF}$ was vacuum heated under a hydrogen atmosphere in a tube furnace at $450{ }^{\circ} \mathrm{C}$ to reduce the oxidized $\mathrm{Cu}$ during the deposition process, according to Eq. (1). Figure 1 shows a schematic representation of the reactions that occurred in the electroless $\mathrm{Cu}$ coating process.

$\mathrm{CuO}+\mathrm{H}_{2} \rightarrow \mathrm{Cu}+\mathrm{H}_{2} \mathrm{O}$

\subsection{Preparation of CF/AI Composites}

$0,5,10,15$, and $20 \mathrm{wt} \%$ uncoated and coated CF reinforced Al composites were manufactured by mixing powders in the ball milling machine (PQ-N2 Planetary Ball Mill) according to parameters listed in Table 2. After this step, the two groups of powders were placed into $\varnothing 10 \mathrm{~mm}$ heat-treated W304 stainless steel. After that, the powders were experienced to relatively low pressure. Then, the die was heated in a muffle furnace at $550{ }^{\circ} \mathrm{C}$ for $30 \mathrm{~min}$. Then, the die was immediately transferred to a 30-ton uniaxial press and the powders were pressed at $700 \mathrm{MPa}$ for $10 \mathrm{~s}$. Lastly, the samples were allowed to cool naturally in the air to form cylindrical samples. Schematic representation of CF/Al composites fabrication is presented in Fig. 2.

\subsection{Composites Characterization}

Samples were subjected to metallographic processes through grinding and polishing. After that, composites and powders microstructure were studied using field emission scanning electron microscope (FE-SEM; QUANTAFEG250, Holland), equipped with energy dispersive X-ray (EDAX). $X$-ray diffraction (XRD, model $x$, pert PRO PANalytical) using $\mathrm{Cu} \mathrm{K} \alpha$ radiation $(\lambda=0.15406 \mathrm{~nm})$ was also used to

Table 2 Parameters of ball milling

\begin{tabular}{ll}
\hline Parameter & Value \\
\hline Speed & $250 \mathrm{rpm}$ \\
Weight of powders & $50 \mathrm{~g} /$ vessel \\
Ball to powder ratio (BPR) & $7: 1$ in uncoated powders \\
& $3: 1$ in coated powders \\
Process control agent (PCA) & Hexane \\
Number of hours & $10 \mathrm{~h}$ \\
Ball materials & Zirconia \\
\hline
\end{tabular}

$\mathrm{HCHO}+2 \mathrm{OH}^{-} \stackrel{\text { oxidation reaction }}{\longrightarrow} \mathrm{HCOO}^{-}+\mathrm{H}_{2} \mathrm{O}+\frac{1}{2} \mathrm{H}_{2}+\mathrm{e}^{-} \quad \mathrm{Cu}^{+2}+2 \mathrm{e}^{-} \stackrel{\text { Reduction reaction }}{\longrightarrow} \rightarrow \mathrm{Cu}$

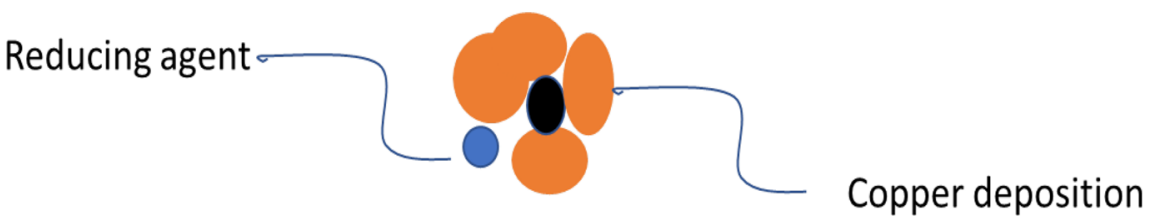

Fig. 1 Schematic representation of the electroless copper coating reactions 


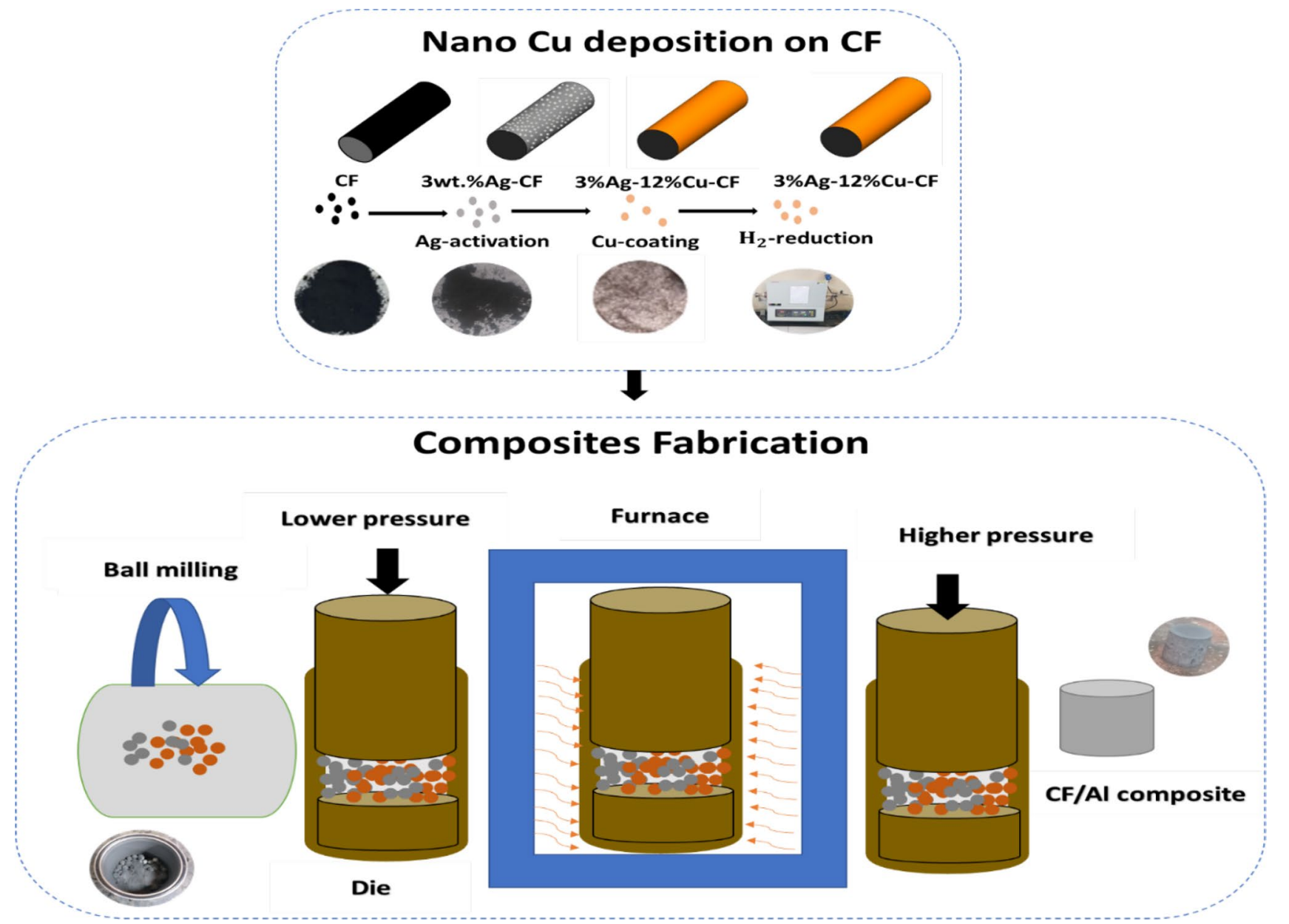

Fig. 2 Schematic illustration demonstrating the steps for preparing CF/Al composites

investigate the phase composition of both powders and consolidated samples during the sintering process. The bulk density of manufactured composites was measured according to Archimedes principles [43]. The theoretical density was calculated using the rule of mixture and the results were compared with experimental values to calculate the relative density. The CTE of composites was measured by a differential dilatometer (NETZSCH DIL 402PC) with a heating rate of $5^{\circ} \mathrm{C} / \mathrm{min}$. The averages of CTE were taken between 100 and $350{ }^{\circ} \mathrm{C}$. Material Tester for Metals (PCE-COM 20) is used to evaluate the electrical conductivity of produced samples. The test was performed along with cylindrical samples $(\varnothing 10 \mathrm{~mm} \times 4 \mathrm{~mm})$ at room temperature. Thermal conductivity was estimated according to the Wiedemann-Franz Law [44]. Microhardness of all composites was observed using Vickers Hardness tester (model HV-1MDT) at an applied load of $300 \mathrm{~g}$ for a holding time of $15 \mathrm{~s}$. The compression test was conducted using a universal test machine (WAW600) according to standard ASTM: E9-09 [45]. The wear test was carried out using a pin-on-disk wear test machine on grounded samples with a $5 \mathrm{~N}$ normal load, sliding speed of $1.45 \mathrm{~m} / \mathrm{s}$ with a rotational speed of 1400 r.p.m without lubrication. These parameters are chosen according to our previous work [46]. An electronic balance with a resolution of $0.1 \mathrm{mg}$ was used to measure the weight of the samples before and after the test. The specific wear rate was measured through the weight loss of samples divided by the product of the sliding distance and normal load. During the test, the friction force was continuously observed, and friction (COF) was calculated.

\section{Results and Discussion}

\subsection{Powders Characterization}

Figure 3a-d show the morphology of $\mathrm{Al}, \mathrm{CF}$, activated and coated $\mathrm{CF}$, respectively. Figure $3 \mathrm{a}$ reveals that $\mathrm{Al}$ powders have an irregular potato shape. In contrast, $\mathrm{CF}$ in Fig. $3 \mathrm{~b}$ has a rod-shaped structure with some epoxy adhered to its surface during its manufacturing process. The activated $\mathrm{CF}$ in Fig. $3 \mathrm{c}$ indicates that nano-silver particles were successfully 

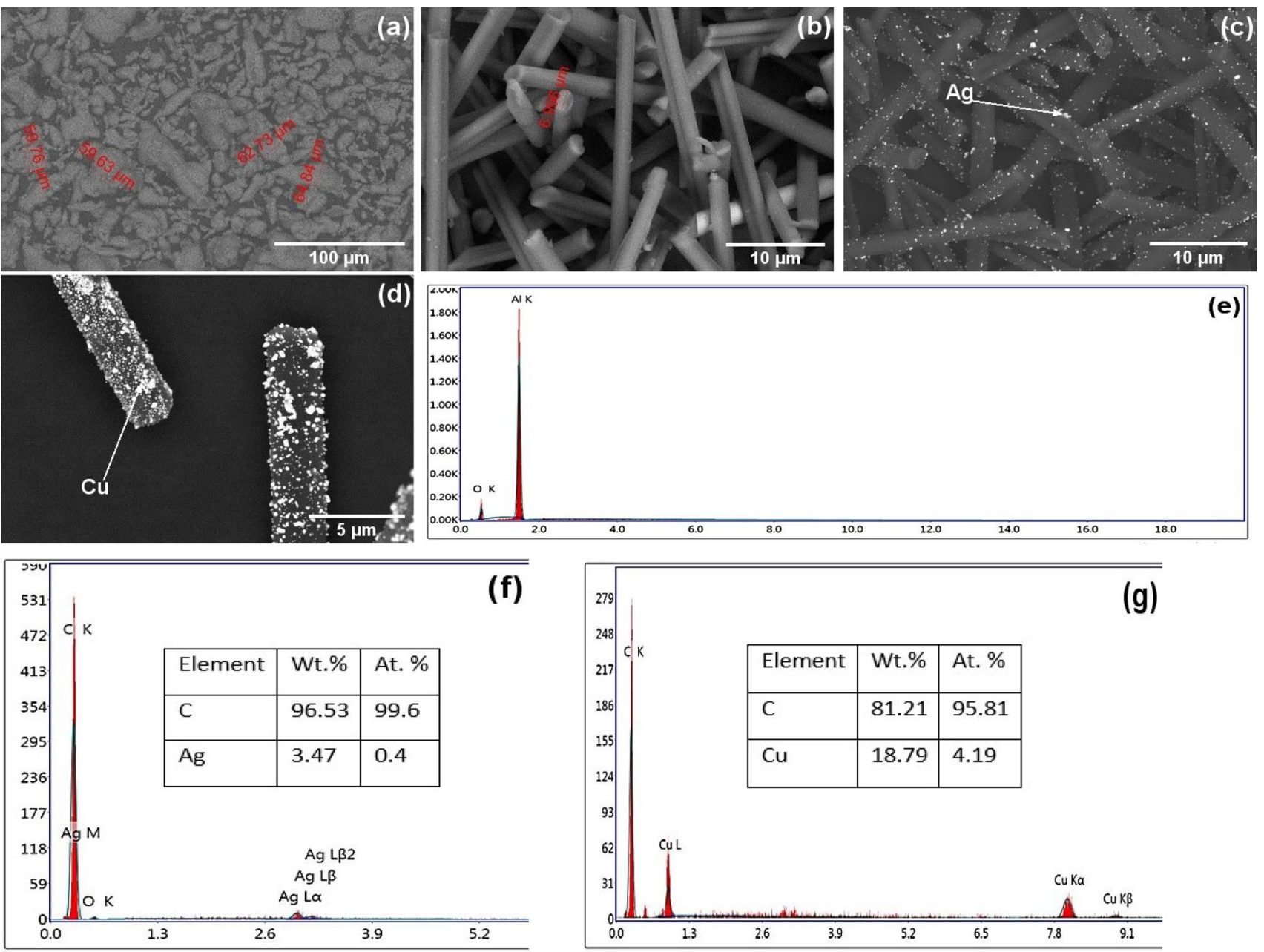

Fig. 3 Morphology of a Al powders, b CF powders, $\mathbf{c}$ Activated CF $\mathbf{d}$ Coated CF, EDAX of $\mathbf{e} \mathrm{Al}$ powders, $\mathbf{f} \mathrm{CF}$ after activation, and $\mathbf{g} \mathrm{CF}$ after Cu coating

deposited and were ready to act as an activation agent for the next process. Figure $3 \mathrm{~d}$ belongs to the coated CF, which indicates that nano $\mathrm{Cu}$ particles have spherical particle shapes that are distributed in a homogenous manner along $\mathrm{CF}$ length. The $\mathrm{Cu}$ layer is continuous and compacted, showing a good bonding between the nano $\mathrm{Cu}$ and $\mathrm{CF}$ surfaces. Figure $3 \mathrm{e}-\mathrm{g}$ are the EDAX analyses of $\mathrm{Al}$ and $\mathrm{CF}$ powders after the activation and coating processes. Figure $3 \mathrm{e}$ shows a small peak of oxygen element in $\mathrm{Al}$ analysis, suggesting that the oxygen element was introduced during the milling operation. On the other hand, the analysis of activated and coated CF reveals a complete compositional analysis for both processes, as shown in Fig. $3 \mathrm{f}$ and $3 \mathrm{~g}$, respectively.

The average length of uncoated and coated CF inside the Al matrix is presented in Fig. 4. The metallic balls during the milling operation have a noticeable influence on the length of reinforcing particles. The particles length after milling was 7.08,8.33,9.87 and $12.12 \mu \mathrm{m}$ for uncoated fiber composites and 6.59,7.83,9.07 and $11.54 \mu \mathrm{m}$ for coated one, which is shorter than that received CF $(100 \mu \mathrm{m})$. In two groups of composites, more reduction in length of $\mathrm{CF}$ particles as $\mathrm{CF}$ percentage increases due to a rise in brittle $\mathrm{CF}$ number in composites. Also, CF length in coated composites is shorter than in uncoated composites. This can be attributed to the variation in the ball to powder ratio between the two types of groups used in this study. It is reported that the higher ball to powder ratio, the more collision between balls which reduces the efficiency of ball milling, resulting in a badly broken of fibers [47, 48]. It is also seen that the diameter of fiber remains constant. Consequently, the aspect ratio of fiber was 1.01,1.19,1.41 and 1.73 for uncoated samples and $0.94,1.11,1.29$ and 1.6 for coated samples.

\subsection{Composites Characterization and XRD}

Figure 5 is the SEM image of CF/Al composites detected in the plane perpendicular to the direction of pressing. Figure 5a represents the pure $\mathrm{Al}$, and b,c,d,e belongs to 

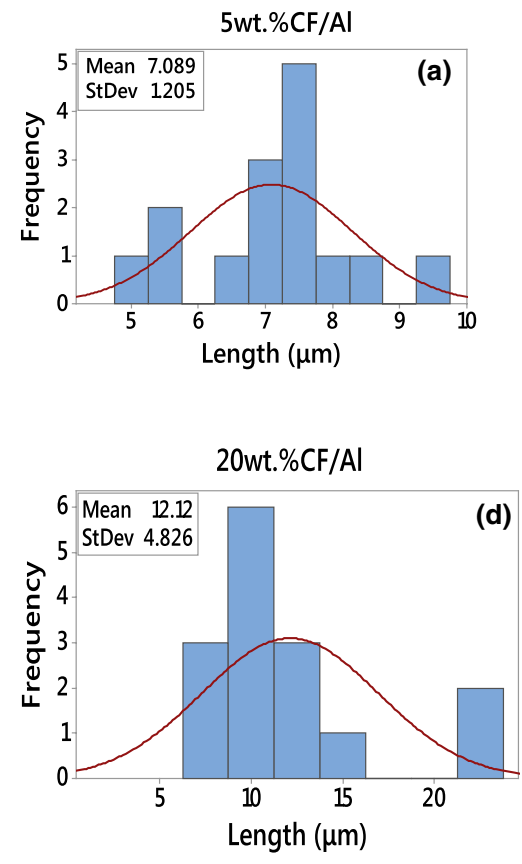
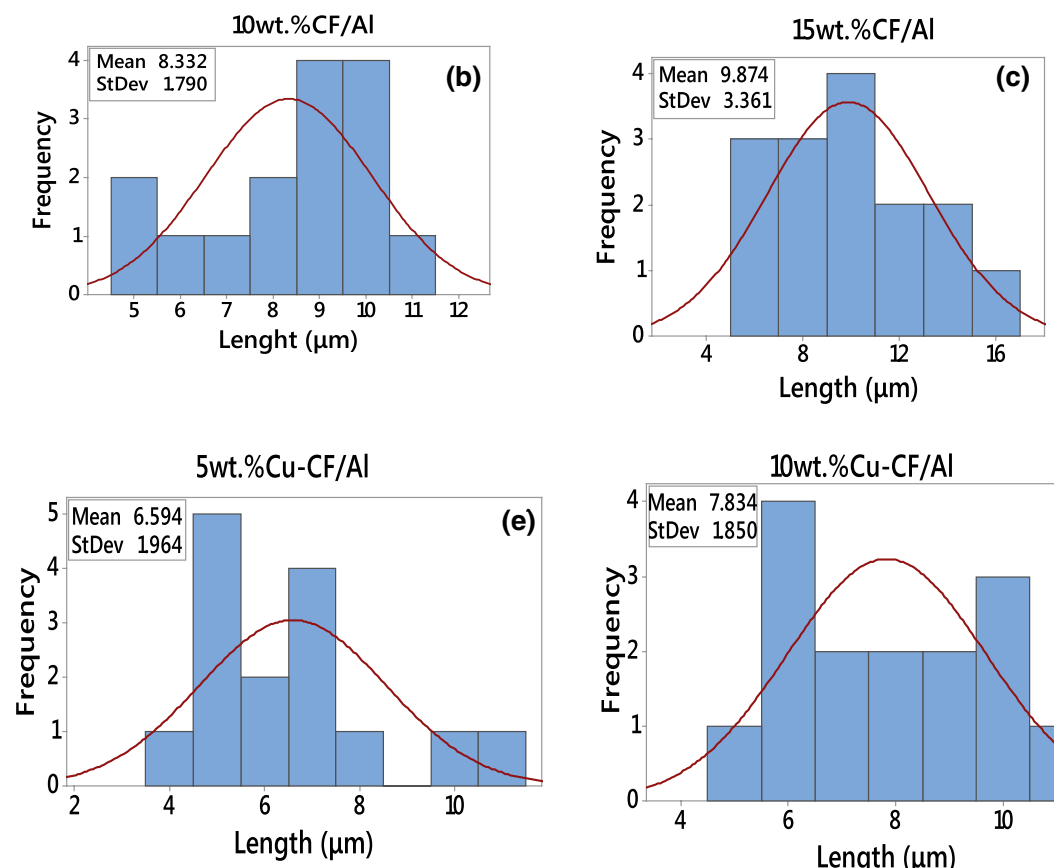

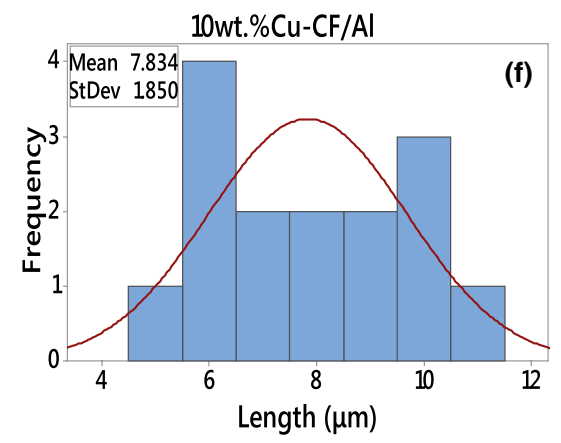

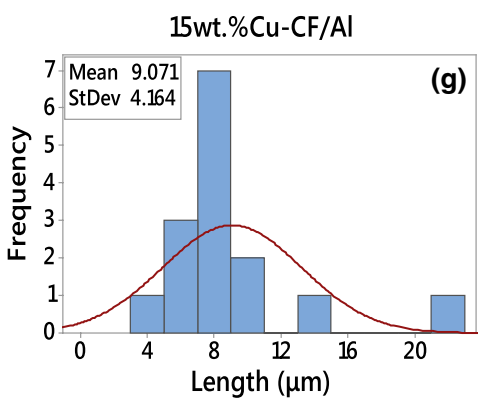

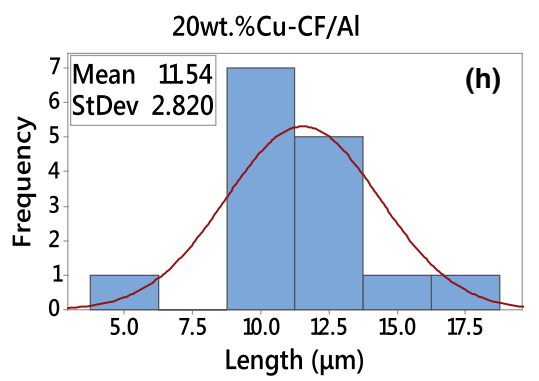

Fig.4 Length distribution of a 5 wt $\%$ CF/Al, b 10 wt $\% \mathrm{CF} / \mathrm{Al}$, c 15 wt $\% \mathrm{CF} / \mathrm{Al}, \mathbf{d} 20$ wt\%CF/Al, CF/Al, e 5 wt $\%$ Cu-coated CF/Al, f 10 wt $\%$ Cucoated CF/Al, g 15 wt $\%$ Cu-coated CF/Al, and h 20 wt $\%$ Cu-coated CF/Al composite

the uncoated $\mathrm{CF} / \mathrm{Al}$ composites, while $\mathrm{f}, \mathrm{g}, \mathrm{h}$, i for the $\mathrm{Cu}$ coated $\mathrm{CF} / \mathrm{Al}$ samples. The bright regions are the $\mathrm{Al}$ matrix while the dark ones are $\mathrm{CF}$ and the white dots correspond to $\mathrm{Cu}$ particles. Most $\mathrm{CF}$ are broken during the milling process, homogeneously dispersed in the $\mathrm{Al}$ matrix, and distributed in the plane perpendicular to the pressing direction due to a uniaxially compressive force during the consolidation process.

It can be seen that $\mathrm{Cu}$ nanoparticles migrate towards $\mathrm{CF}-\mathrm{CF}, \mathrm{CF}-\mathrm{Al}$ and in the Al matrix. Moreover, coated composites have a better fiber distribution in their structure than uncoated ones. This can be explained by improving the wettability between the $\mathrm{CF}$ that has a ceramic nature and the metallic $\mathrm{Al}$ matrix by encapsulating the $\mathrm{CF}$ with nano metallic $\mathrm{Cu}$, so the surface energy between the two constituents decreases. However, for the uncoated CF/Al composites, the non-wettability problems increase in the collection of CF particles, which appear as agglomerations in the Al matrix.
Higher magnification of the SEM images are demonstrated in Fig. 6 to study the interfacial structure of composites. For uncoated composites, the pores appear at the interface, explaining that interfacial bonding is very weak. On the contrary, in coated composites, good interfacial bonding between the $\mathrm{Al}$ matrix and $\mathrm{CF}$ where pores are absent at the interface. From the literature, it was concluded that the porosity could cause a drop in the properties of composites. This result indicates that $\mathrm{Cu}$ coating is an efficient process to improve bonding between $\mathrm{Al}$ and CF. EDAX analysis in Fig. 7 of $10 \mathrm{wt} \%$ CF composites is used to check the sample composition at the interface. It can be indicated that $\mathrm{Al}$ matrix and $\mathrm{CF}$ have been identified at the interface without any contaminations in uncoated CF composites. While in the coated composites, the EDAX results indicate the presence of $\mathrm{C}, \mathrm{Ag}, \mathrm{Cu}$ and $\mathrm{Al}$ at the interface, indicating an excellent interfacial adhesion.

The pattern in Fig. 8a revealed that only $\mathrm{Al}$ peaks at $2 \theta$ $=38.42^{\circ}, 44.60^{\circ}, 64.95^{\circ}, 78.09^{\circ}$ and $82.30^{\circ}$ which correspond 

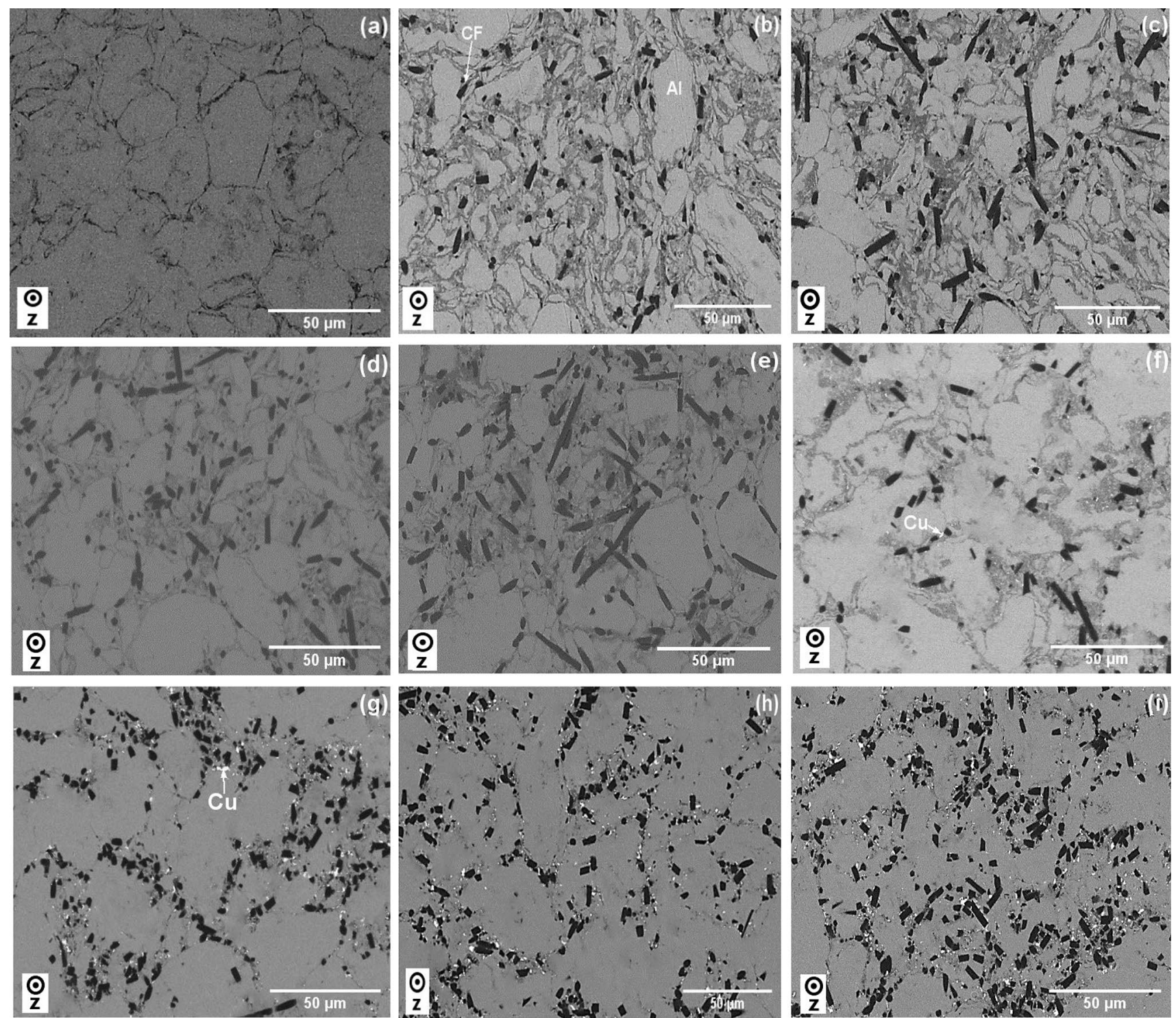

Fig. 5 Microstructure of $\mathrm{CF} / \mathrm{Al}$ composites observed on the plane perpendicular to pressing direction a pure $\mathrm{Al}$, b $5 \mathrm{wt} \% \mathrm{CF} / \mathrm{Al}$, c 10 wt $\% \mathrm{CF} / \mathrm{Al}$, d 15 wt $\%$ CF/Al, e 20 wt $\% \mathrm{CF} / \mathrm{Al}$, f 5 wt $\%$ Cu-coated

to (111), (200), (220), (311), and (222) crystal planes are observed in Al powders, respectively. While Fig. $8 \mathrm{~b}$ presents the $\mathrm{CF}$, activated $\mathrm{Ag}$ and coated $\mathrm{Cu}$ elements in coated $\mathrm{CF}$ powder analysis. It is also observed in the study that one small peak for $\mathrm{Cu}_{2} \mathrm{O}$ at $2 \theta=36.32^{\circ}$ correspond to (111) crystal plane. Results of $\mathrm{CF} / \mathrm{Al}$ composites are presented in Fig. 8c. As expected, the XRD pattern shows the main $\mathrm{Al}$ peaks, and the primary $\mathrm{CF}$ peak at $\left(2 \theta=26.2^{\circ}\right)$ corresponds to (002) crystal plane, which could only be detected in 15 and $20 \mathrm{wt} \% \mathrm{CF}$. Moreover, no $\mathrm{Al}_{4} \mathrm{C}_{3}$ was found in all composites showing that the harmful reactions between $\mathrm{Al}$ and $\mathrm{CF}$ are absent during the sintering process. For coated composites, the intermediate $\mathrm{Al}_{2} \mathrm{Cu}$ phase isn't detected in
CF/Al, g 10 wt\% Cu-coated CF/Al, h 15 wt\% Cu-coated CF/Al, i 20 wt $\% \mathrm{Cu}$-coated $\mathrm{CF} / \mathrm{Al}$ composite. ( $\mathrm{Z}$ axis indicates the pressing direction)

the XRD pattern because of the low content of $\mathrm{Cu}$ used and our controllable consolidation process. Scherrer's formula in Eq. (2) is used to calculate the crystallite size of the produced composites.

$d=\frac{0.9 \lambda}{B \cos \theta}$

where $d$ is the crystallite size, $\lambda$ is the wavelength of the radiation, $\theta$ is the Bragg's angle, and $B$ is the full width at half maximum [45]. It is evident from Table 3 that the addition $\mathrm{CF}$ and the electroless coating process have a critical role in the crystallite size reduction of composites. This may be attributed to two reasons; the first is the effect of a ceramic 

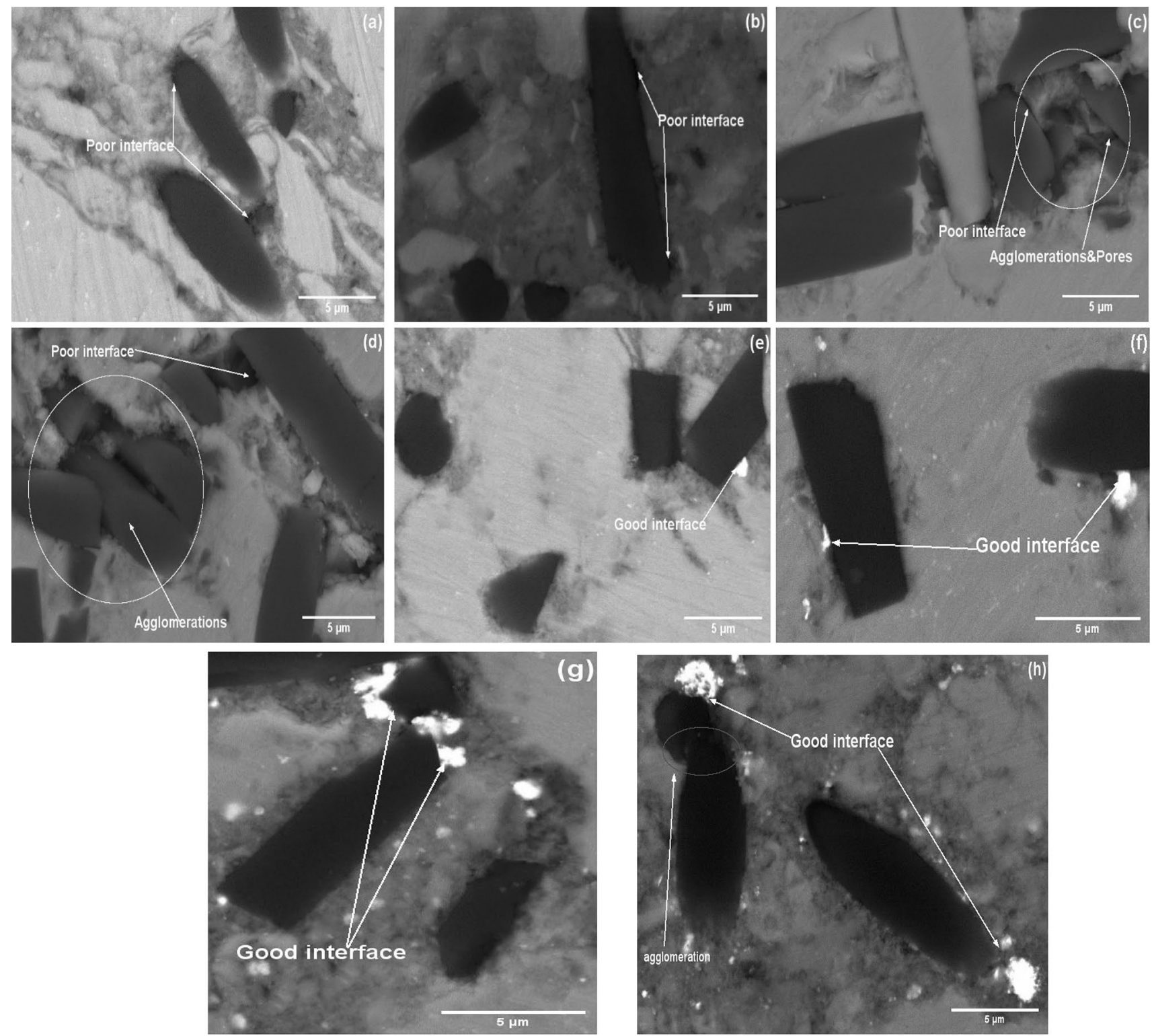

Fig. 6 Microstructure of CF/Al composites with higher magnification a 5 wt\% CF/Al, b 10 wt\% CF/Al, c 15 wt\% CF/Al, d 20 wt\% CF/Al, e 5 wt \% Cu-coated CF/Al, f 10 wt \% Cu-coated CF/Al, g 15 wt\% Cu-coated CF/Al, and h 20 wt\% Cu-coated CF/Al composite

nature that acts as internal balls, causing a reduction of particle size. The second is the coating process in which nano $\mathrm{Cu}$ particles are mostly distributed on the boundaries of $\mathrm{Al}$ grains, as shown in Fig. 5, restricting the growth of Al grains in the consolidation process and resulting in a smooth and fine surface. Therefore, in coated composites, more grains are formed and the grain growth is restrained, thus causing grain refinement. Such a decrease in grain size can positively affect the mechanical properties of composites. Many studies confirmed the enhancement of mechanical properties due to the refining process of grain size $[49,50]$.

\subsection{Density Measurement}

The theoretical and experimental densities of the composites along with the corresponding weight fraction of reinforcement are presented in Table 4. It is observed that the measured density of composites decreased with CF contents and was in line with the values obtained by the rule of mixtures. This can be attributed to the low density of reinforcement $(1.8 \mathrm{~g} / \mathrm{cm} 3)$ compared to $\mathrm{Al}(2.7 \mathrm{~g} / \mathrm{cm} 3)$. Additionally, the measured density has lower values than the theoretical one. This difference is attributable to the existence of voids and 

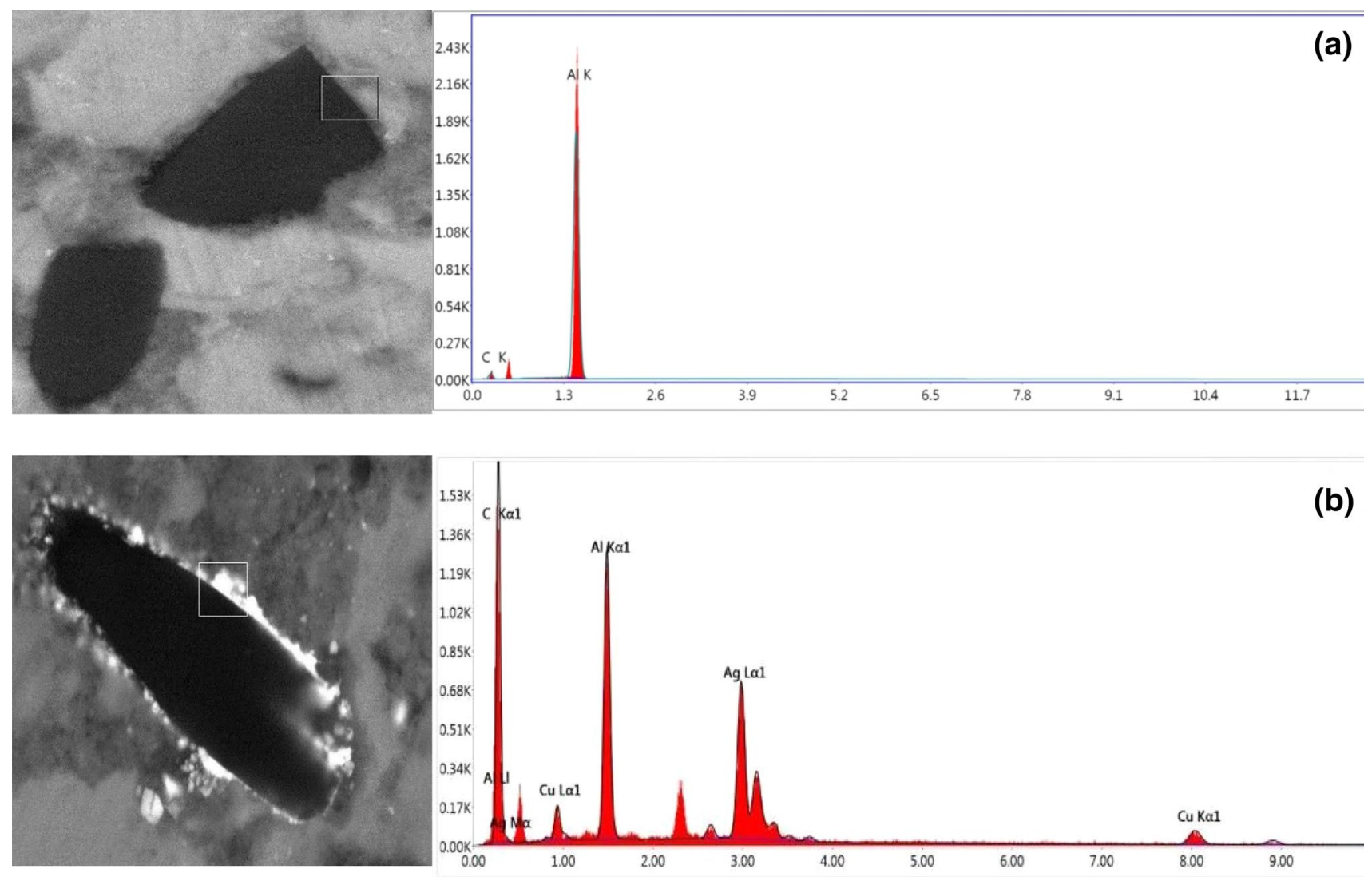

Fig. 7 EDAX analysis of a $10 \mathrm{wt} \% \mathrm{CF} / \mathrm{Al}$ composite and b $10 \mathrm{wt} \% \mathrm{Cu}$-coated CF/Al composite

pores in the composites. The agglomerations and voids are an acute issue in metals matrix composites fabrication. It is hard to disperse $\mathrm{CF}$ in $\mathrm{Al}$ matrix without forming CF clusters, especially at a higher reinforcement ratio. Examining the degree of voids and agglomerations in this study, in case uncoated composites, the percentage of void in $10 \mathrm{wt} \% \mathrm{CF}$ composite was $7.48 \%$ (see Table 4 ) and the agglomerations were absent in composite (see Fig. 6. b). These voids then increased significantly to $8.6 \%$ and $10.31 \%$ in 15 and 20 wt $\%$ CF composites, respectively and the agglomerations were prominently shown (see Fig. 6. c and d). However, the pore percentage in $10 \mathrm{wt} \% \mathrm{Cu}$-coated samples was $5.1 \%$, which increased to more than $7 \%$ in both 15 and $20 \mathrm{wt} \%$ $\mathrm{CF}$ composites. Moreover, the agglomerations were hardly only detected in $20 \mathrm{wt} \% \mathrm{CF}$ sample (see Fig. 6.h). These agglomerations could reduce the potential enhancement in the properties of CF composites.

Figure 9 show the effect of both CF content and coating process on the relative density of $\mathrm{CF} / \mathrm{Al}$ composites. There are two phenomena observed: one is the higher relative density value of the $\mathrm{Cu}$-coated samples than the uncoated ones. This can be explained by the improved wettability between $\mathrm{CF}$ and $\mathrm{Al}$ due to the nano $\mathrm{Cu}$ coating process. The contact angle between $\mathrm{Al}$ and $\mathrm{Cu}$ is lower than that between $\mathrm{Al}$ and
CF, so good densification takes place in coated composites. Also, the presence of nano metallic materials such as $\mathrm{Cu}$ and $\mathrm{Ag}$ facilitates the interconnection between the large micro$\mathrm{Al}$ particles and $\mathrm{CF}$ particles, consequently, the densification rate increases. As we said earlier, the pores at the interface are easily filled with nano $\mathrm{Cu}$ particles to produce high relative density composites (see Fig. 6).

The second phenomenon is decreasing the relative density by increasing the CF percentage. The higher the content of $\mathrm{CF}$, the more agglomeration areas are formed, which contributes to more gaps in the structure. Fathy et al. [51] reported that incorporating ceramic materials into metallic matrices could form a close network that acts as a barrier of Al diffusion, reducing particles connection and many agglomerations and porosity levels are created during the sintering process. Hard ceramic reinforcements increase the compaction pressure required for composite densification. It is also shown that composites have high relative density values, suggesting that our consolidation technique and high sintering temperature are excellent, resulting in easier diffusion between reinforcement and matrix. Also, the mixed powders are consolidated under both mechanical and thermal loads, so a good interaction between the $\mathrm{Al}$ particles and CF occurs, and consequently, low pores are recorded. 

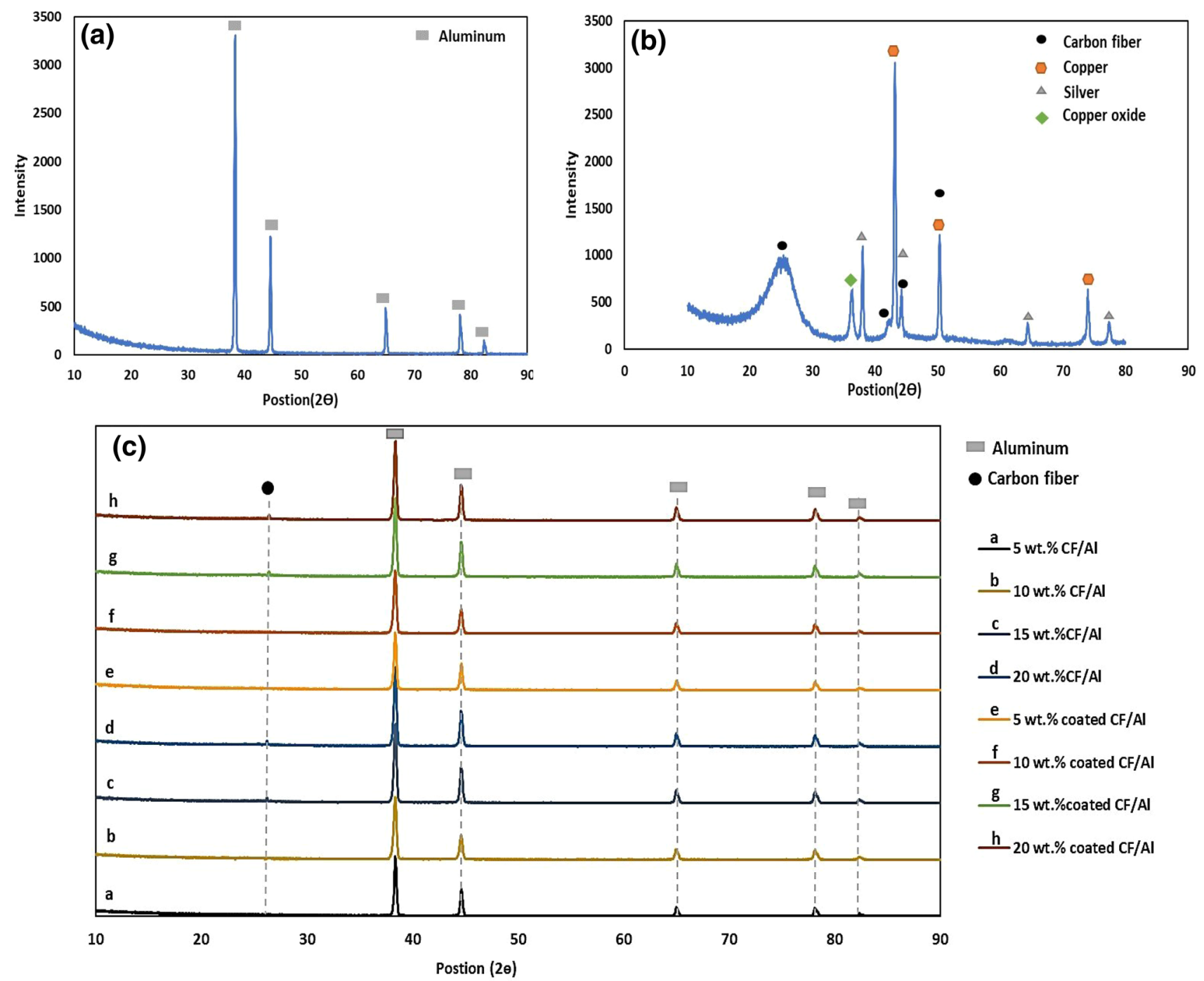

$\square$ Aluminum

- Carbon fiber

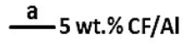

b 10 wt.\% CF/Al

C $15 \mathrm{wt} . \% \mathrm{CF} / \mathrm{Al}$

d $20 \mathrm{wt} . \% \mathrm{CF} / \mathrm{Al}$

e 5 wt.\% coated CF/Al

f 10 wt.\% coated CF/Al

g 15 wt.\%coated CF/Al

$\mathrm{h}_{20} \mathrm{wt} . \%$ coated CF/Al

Fig. $8 \mathrm{XRD}$ results of $\mathbf{a} \mathrm{Al}$ powders, $\mathbf{b} \mathrm{CF}$ powders after $\mathrm{Cu}$ coating, and $\mathbf{c} \mathrm{CF} / \mathrm{Al}$ composites

Table 3 Crystallite size of produced composites

\begin{tabular}{lll}
\hline Wt\% CF & $\begin{array}{l}\text { Crystallite size }(\mathrm{nm}) \\
\text { Uncoated samples }\end{array}$ & Coated samples \\
\hline 0 & 39.59 & \\
5 & 38.25 & 39.06 \\
10 & 36.45 & 24.82 \\
15 & 35.16 & 24.26 \\
20 & 33.89 & 23.88 \\
\hline
\end{tabular}

\subsection{Coefficient of Thermal Expansion (CTE)}

Figure 10 shows the CTE of the prepared composites with temperatures varying from 100 to $350^{\circ} \mathrm{C}$. It is noted that the CTE of all composites increases with increasing temperature due to the change in the internal stress of composites.
Table 4 Measured density, theoretical density and void fraction of the sintered samples of $\mathrm{CF} / \mathrm{Al}$

\begin{tabular}{llllc}
\hline Materials & Conditions & $\begin{array}{l}\text { Measured } \\
\text { density }(\mathrm{g} / \\
\mathrm{cm} 3)\end{array}$ & $\begin{array}{l}\text { Theoretical } \\
\text { density }(\mathrm{g} / \\
\mathrm{cm} 3)\end{array}$ & Void \% \\
\hline Pure Al & & 2.62 & 2.7 & 2.97 \\
$5 \mathrm{wt} \%$ & Without coating & 2.47 & 2.65 & 6.8 \\
$10 \mathrm{wt} \%$ & & 2.41 & 2.61 & 7.48 \\
$15 \mathrm{wt} \%$ & & 2.34 & 2.56 & 8.6 \\
$20 \mathrm{wt} \%$ & & 2.25 & 2.52 & 10.31 \\
$5 \mathrm{wt} \%$ & With coating & 2.57 & 2.697 & 4.8 \\
$10 \mathrm{wt} \%$ & & 2.55 & 2.694 & 5.1 \\
$15 \mathrm{wt} \%$ & & 2.50 & 2.691 & 7.1 \\
$20 \mathrm{wt} \%$ & & 2.49 & 2.69 & 7.5 \\
\hline
\end{tabular}


Fig. 9 The relative density of $\mathrm{CF} / \mathrm{Al}$ composites

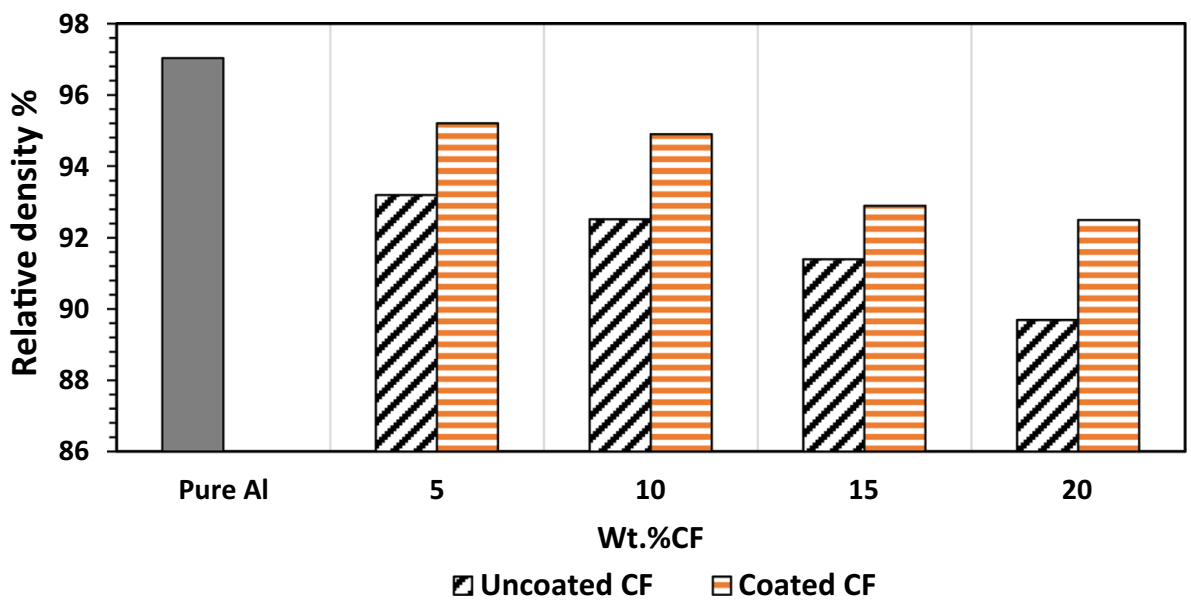

Fig. 10 CTE curves of the $\mathrm{CF} /$ Al composites against temperatures

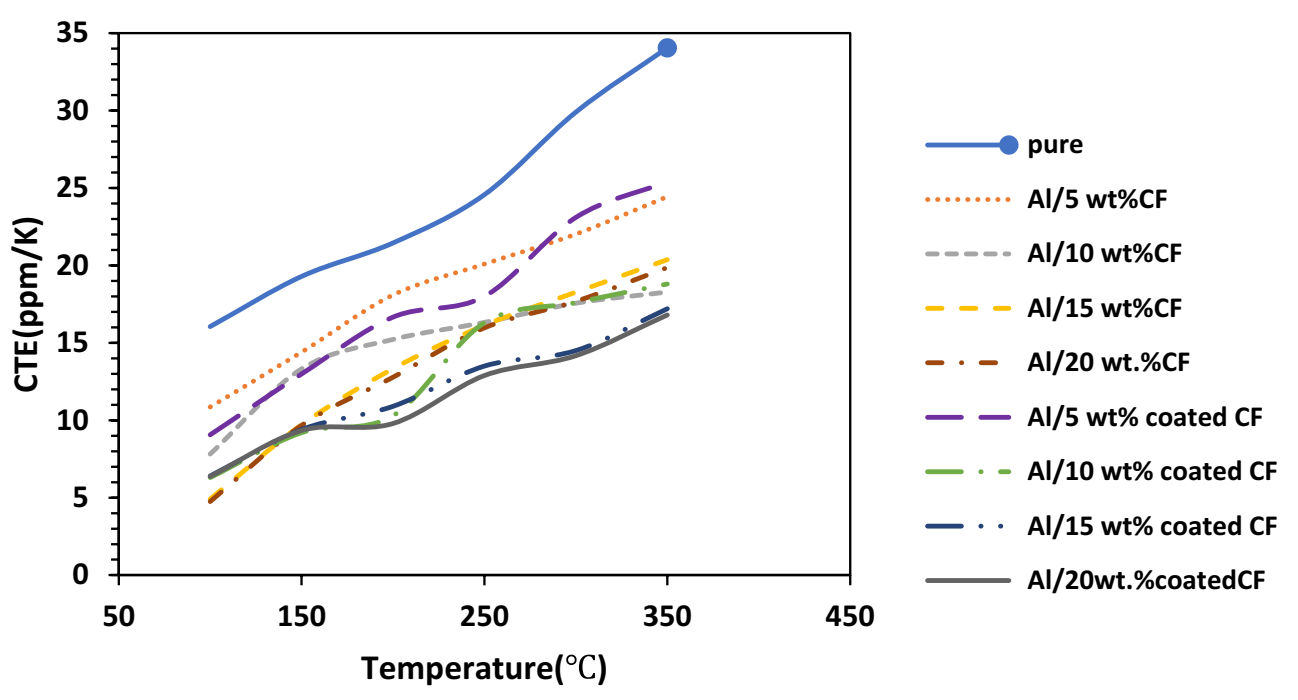

Residual stress is generated when composites are cooled from sintering temperature to room temperature during the preparation process due to the large variation in CTE between $\mathrm{Al}$ and $\mathrm{CF}$. This residual stress acts as compressive stress on CF and tensile stress on the Al matrix. So, when samples are heated during the test, the tensile stress on the matrix is released, and $\mathrm{Al}$ begins to expand [52]. The effect of opposite stresses on CF can be neglected because of the large modulus and strength of CF compared to Al.

On the other hand, Fig. 11 presents the relation between experimental and calculated CTE based on ROM and the turner model [53]. It is noted that the CTE of all CF/Al composites is lower than that of the Al matrix and decreases with an increase in CF. For instance, as compared to Pure Al, the CTE of composites is reduced by $38 \%$ and $41.7 \%$ at $20 \mathrm{wt} \%$ of uncoated and coated CF, respectively. Reduction in CTE values is due to the restriction effect of CF on Al expansion. The electroless coating was an effective way to minimize expansion. $\mathrm{Cu}$-coated $\mathrm{CF}$ composites have relatively lower CTE than uncoated composites. This is due to better interfacial bonding that improves Al thermal stability. Low interfacial resistance reduces the CF restriction effect [54]. Additionally, theoretical values are higher than the experimental ones due to the small size of CF particles used in this study which have a large surface area, leading to an increase in direct contact with $\mathrm{Al}$ particles at the interface and more thermal expansion reduction. Much reduction in size could be achieved during the milling operation that enhanced the thermal expansion restriction process.

\subsection{Electrical Conductivity}

The values of electrical conductivity of $\mathrm{CF} / \mathrm{Al}$ composites are presented in Fig. 12. For uncoated composites, the addition of $10 \mathrm{wt} \% \mathrm{CF}$ to the $\mathrm{Al}$ matrix improves the electrical conductivity of composites from $21.1 \mathrm{MS} / \mathrm{m}$ to $25.88 \mathrm{MS} / \mathrm{m}$. Increasing uncoated fiber content to $15 \mathrm{wt} \%$ and $20 \mathrm{wt} \%$ decreases the conductivity to $17.39 \mathrm{MS} / \mathrm{m}$ and $16.89 \mathrm{MS} / \mathrm{m}$, 

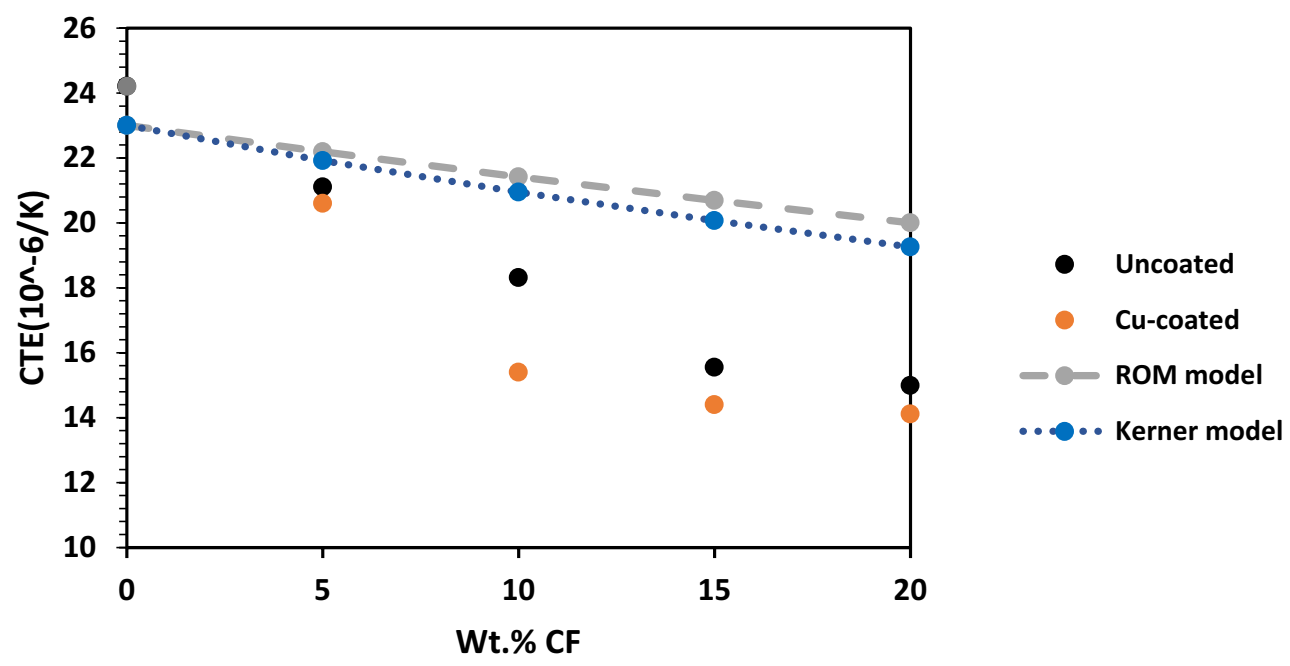

Fig. 11 Comparison between the experimental CTE and the calculated CTE based on the rule of mixture (ROM) and the Turner model as a function of $\mathrm{CF}$ percentage in the $\mathrm{CF} / \mathrm{Al}$ composites

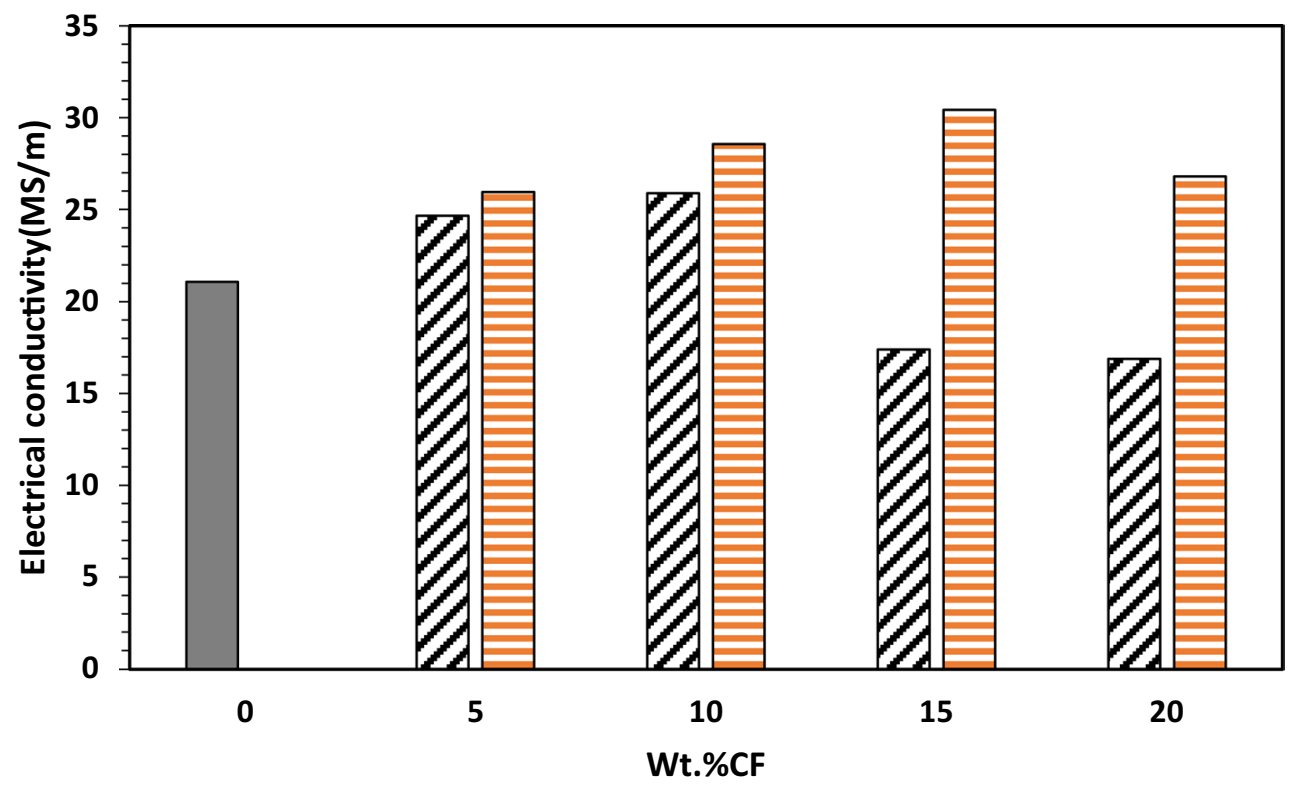

Quncoated Cf $\square$ coated Cf

Fig. 12 Electrical conductivity of $\mathrm{CF} / \mathrm{Al}$ composites

respectively. Meanwhile, the highest electrical conductivity value is $30.43 \mathrm{MS} / \mathrm{m}$ for $15 \mathrm{wt} \% \mathrm{Cu}$-coated $\mathrm{CF} / \mathrm{Al}$ composite. Examining the electrical conductivity of $\mathrm{CF} / \mathrm{Al}$ composites, the existence of conductive reinforcements in the $\mathrm{Al}$ matrix increases the number of conductive paths and facilitates the movement of the electrons. Also, the distribution of $\mathrm{CF}$ along the $\mathrm{Al}$ grain boundary contributes to increasing the conductivity of composites [55]. In fact, the conductivity declines after $10 \mathrm{wt} \%$ for uncoated composites owing to the agglomerations and pores formed at the interface. The conductivity of pores is zero, so their presence in the samples hinders the motion of the electrons and decreases the overall conductivity of the prepared samples [56]. It is stated that defects and low interfacial bonding are the main reasons for restricting electrons motion and increasing electrical resistivity [57, 58]. As mentioned earlier, the number of defects in coated composites was less than that of uncoated ones. So, the electrical conductivity of coated composites continues to 
improve after $10 \mathrm{wt} \%$ and exhibits better conductivity than uncoated ones. In summary, the addition of CF to the Al matrix has an excellent effect on the electrical performance if only the bonding between matrix and reinforcement is strong and fibers are homogenously distributed in the matrix without any agglomerations.

\subsection{Thermal Conductivity (TC)}

Figure 13 shows the TC of CF/Al composites containing uncoated and coated $\mathrm{CF}$ with different weight fractions. With increasing uncoated fiber from $0 \mathrm{wt} \%$ to $10 \mathrm{wt} \% \mathrm{CF}$, TC of composite rises from $154.9 \mathrm{~W} \cdot \mathrm{m}^{-1} \cdot \mathrm{K}^{-1}$ to $190.21 \mathrm{~W} \cdot \mathrm{m}^{-1} \cdot \mathrm{K}^{-1}$. The TC values of composite begin to drop with more reinforcement, while $\mathrm{Cu}$-coated $\mathrm{CF} / \mathrm{Al}$ composites keep improving and increase to $223.6 \mathrm{~W} \cdot \mathrm{m}^{-1} \cdot \mathrm{K}^{-1}$ at $15 \mathrm{wt} \% \mathrm{CF}$. CF could enhance the TC of the $\mathrm{Al}$ matrix due to the high TC of $\mathrm{CF}$. Reduction in the TC of uncoated composites at 15 and $20 \mathrm{wt} \%$ $\mathrm{CF}$ and for coated composites at $20 \mathrm{wt} \% \mathrm{Cu}$ coated CF can be attributed to the creation of voids in the structure, which reduce heat conduction and act as an inhibitor for TC linear growth. The presence of pores decreases TC as the conductivity of the pores is zero, which greatly affects The TC of composites. Pores are considered thermal insulators that have a bad effect on the thermal properties of composites [38, 57]. The electroless $\mathrm{Cu}$ coating process could improve the TC of composites due to the high thermal conductivity of the metallic layer itself and its rule to enhance wetting and reduce the interfacial defects, especially at a higher percentage of reinforcement. $\mathrm{Cu}$ coating layer could transform the wettability from between fiber and matrix to two metallic layers, thereby enhancing the TC of composites [59]. Similar observations were reported on $\mathrm{TC}$ of $\mathrm{CF} / \mathrm{Mg}$ composites where the $\mathrm{Cu}$ layer significantly enhanced the interfacial bonding and thus improved the TC of composites [60].

\subsection{Hardness Estimation}

Figure 14 explains the effect of $\mathrm{CF}$ and $\mathrm{Cu}$ coating on the hardness of $\mathrm{CF} / \mathrm{Al}$ composites. It shows a continuous increase in the hardness values by increasing the $\mathrm{CF}$ content for the nano $\mathrm{Cu}$-coated $\mathrm{CF}$ samples. But it improved up to $10 \mathrm{wt} \%$ then decreased for the uncoated groups. The microhardness of the $\mathrm{Al}$ composites has increased from $0.342 \mathrm{GPa}$ at neat composite to $0.47 \mathrm{GPa}$ at $10 \mathrm{wt} \%$ uncoated $\mathrm{CF}$ and $0.74 \mathrm{GPa}$ at $20 \mathrm{wt} \%$ coated CF /Al composite, with increasing percentages of $37.7 \%$ and $114.89 \%$, respectively. The improvement in hardness values may be attributed to an increase in CF particles content, which leads to a decrease in the spacing between particles and an increase in the stress required to induce dislocation movement. This can be proved by the following Equations [61]:

$\lambda=\frac{4(1-\mathrm{f}) \mathrm{r}}{3 \mathrm{f}}$

$\tau_{0}=\frac{\mathrm{Gb}}{\lambda}$

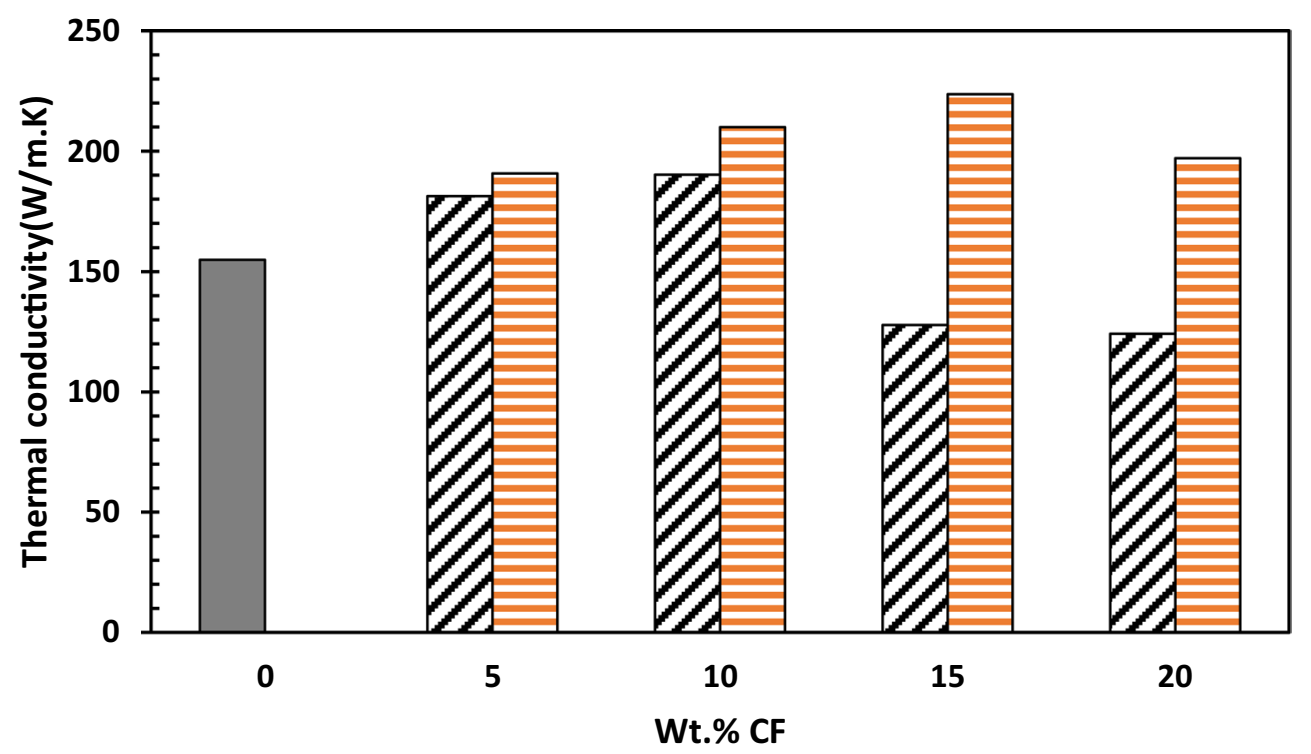

a Uncoated fiber $\square$ Coated fiber

Fig. 13 Thermal conductivity of CF/Al composites 


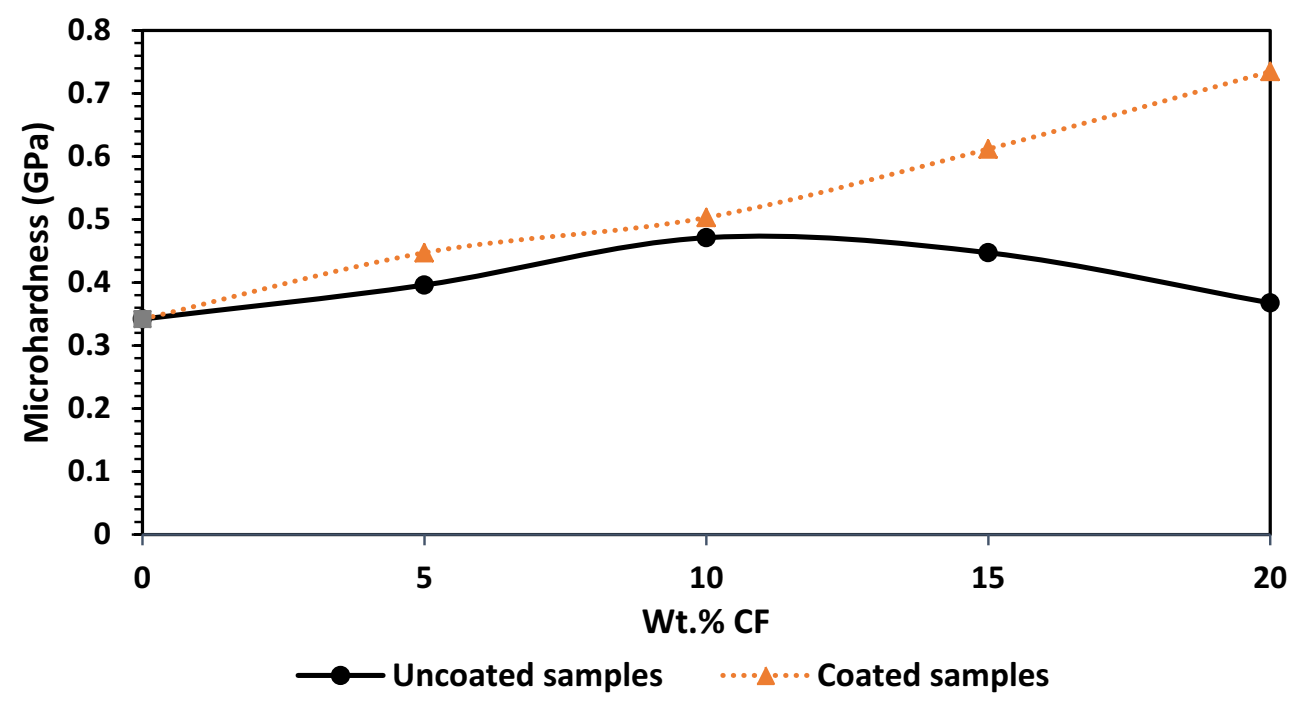

Fig. 14 Microhardness of pure $\mathrm{Al}$ and $\mathrm{Al}$ composites reinforced with $\mathrm{CF}$ with and without $\mathrm{Cu}$ coating

where $\lambda$ is the reinforcement distance,f volume fraction of particles, $r$ is CF radius (assume CF particles is spheri$\mathrm{cal}), \tau_{0}$ is the shear stress, $\mathrm{G}$ is the shear modulus, and $\mathrm{b}$ is the burger's vector.

Moreover, incorporating hard ceramic particles into ductile materials with a uniform distribution could reduce grain size, which has a positive effect on the hardness of composites [46]. The reduction in hardness value after $10 \mathrm{wt} \%$ uncoated CF may occur because the hardness is affected by other detrimental factors such as aggregation and relative density reduction. Also, coating $\mathrm{CF}$ with nano $\mathrm{Cu}$ layers causes the reduction of particles and crystallite size, which improves the hardness values according to the Hall Petch equation. The previous result is consistent with studies [11, $62]$.

The electroless $\mathrm{Cu}$ coating role is significant, especially at a higher fraction of reinforcement, where the agglomeration and debonding of uncoated composites are present. By comparing the two groups, the microhardness of coated composites is clearly enhanced by $36.82 \%$ and $99.9 \%$ at 15 and 20 wt\% CF compared to uncoated composites, respectively. The electroless $\mathrm{Cu}$ coating could prevent the non-homogeneity, agglomerations of reinforcement in the matrix and refine the grain size of composites. Thus, the ability of the composite to resist indentation increased. Urena et al. [42] stated that $\mathrm{Cu}$ coating caused an improvement in hardness for $\mathrm{Al}$ composites due to metastable precipitated phases.

\subsection{Compression Test}

The compression stress-strain diagram of sintered specimens is shown in Fig. 15. The effect of two parameters on compressive strength and ductility of composites is studied in Table 5. It is shown that the strength of the base material is higher than its composites. For instance, when $20 \mathrm{wt} \%$ $\mathrm{CF}$ was added into the $\mathrm{Al}$ matrix, compressive strength was reduced by $34.18 \%$ for uncoated composites and $21.56 \%$ for coated composites compared to that of pure Al. Fracture mode, presence of porosity, refining grain size and uniform distribution of reinforcement are variables that affect compressive strength value $[56,63,64]$. CF could convert the fracture system from ductile to fracture mode, reduce the relative density of the $\mathrm{Al}$ matrix and increase porosity and agglomerations. Pores and agglomerations are considered stress concentration regions where $\mathrm{CF}$ is easily broken in these areas under compressive force. These phenomena could vanish the positive effect of grain refinement and reduce composites resistance to fracture. This result matches with studies of $[63,65]$. On the other side, the effect of CF on ductility was noticeable where ductility is reduced as the weight fraction of CF increases due to the hard ceramic natures of CF. The $20 \mathrm{wt} \%$ uncoated CF composite has the lowest strain value, with $40.2 \%$ lower than the monolithic sample. Generally, CF could impede more deformations of composites under compression force.

It is also noticed that there is an improvement of compressive strength and ductility values for metal-coated $\mathrm{CF} /$ $\mathrm{Al}$ composites rather than uncoated ones. This improvement was small at low CF content and became significant at higher $\mathrm{CF}$ content. Improving the interfacial bonding between $\mathrm{Al}$ and $\mathrm{CF}$ and the homogenous distribution of reinforcement improved the load transfer from $\mathrm{Al}$ to $\mathrm{CF}$ and reduced the possibility of cracks. According to Orwan model, composites with agglomerated particles have higher interparticle spacing and lower strength than composites with uniform distribution ones [66]. Ductility of material depends on grain 
Fig. 15 Compressive stressstrain diagram of pure $\mathrm{Al}$ and $\mathrm{Al}$ composites reinforced by $\mathrm{CF}$ with and without $\mathrm{Cu}$ coating

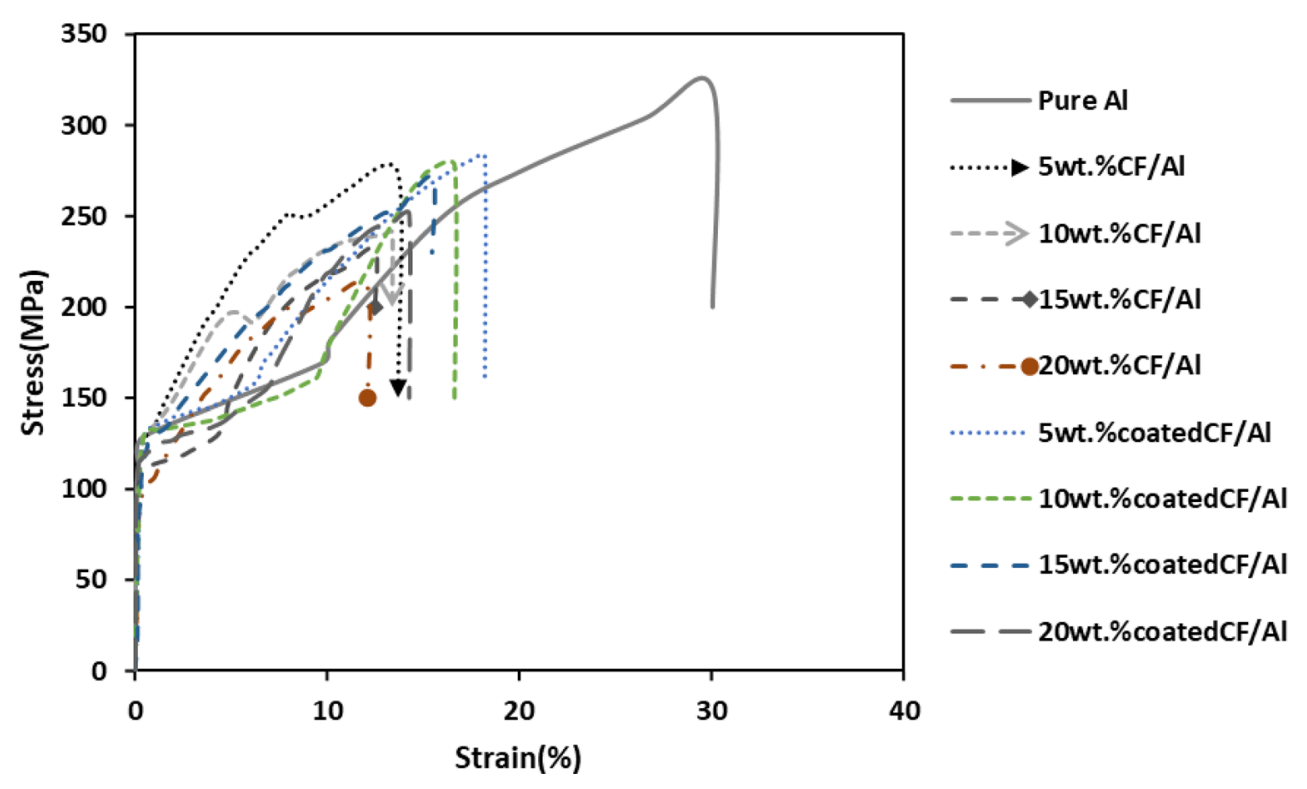

Table 5 The compression strength and elongation at fracture of $\mathrm{CF} /$ $\mathrm{Al}$ composites

\begin{tabular}{lll}
\hline Samples & $\begin{array}{l}\text { Ultimate strength } \\
(\mathrm{MPa})\end{array}$ & $\begin{array}{l}\text { \%Elongation } \\
\text { (Ductility) }\end{array}$ \\
\hline Pure Al & 320.30 & 30.06 \\
$5 \mathrm{wt} \% \mathrm{CF} / \mathrm{Al}$ & 273.78 & 13.70 \\
$10 \mathrm{wt} \% \mathrm{CF} / \mathrm{Al}$ & 241.12 & 13.39 \\
$15 \mathrm{wt} \% \mathrm{CF} / \mathrm{Al}$ & 232.22 & 12.49 \\
$20 \mathrm{wt} \% \mathrm{CF} / \mathrm{Al}$ & 210.80 & 12.11 \\
$5 \mathrm{wt} \% \mathrm{Cu}-\mathrm{coated} \mathrm{CF} / \mathrm{Al}$ & 282.94 & 18.21 \\
$10 \mathrm{wt} \% \mathrm{Cu}-$ coated CF/Al & 277.60 & 16.64 \\
$15 \mathrm{wt} \% \mathrm{Cu}-$ coated/Al & 271.76 & 15.46 \\
$20 \mathrm{wt} \% \mathrm{Cu}-$ coated/Al & 251.22 & 14.28 \\
\hline
\end{tabular}

size, which ductility is reduced with increasing grain size [67]. So, the values of ductility of coated composites are higher compared to uncoated samples. Also, Agglomerated reinforcements significantly decrease the ductility of composites, as reported in the former studies [68, 69]. The uniform distribution of fiber in coated composites increases the ability to withstand deformation without fracture, resulting in large material elongations.

The microstructure of fracture surfaces of $20 \mathrm{wt} \% \mathrm{CF}$ compression test samples were investigated to study further the coating layer's effect on fracture of composites. As shown in Fig. 16a, most CF is pulled out (marked as circles) in uncoated samples and extracted from the matrix, indicating the bonding between matrix and fiber at the interface was weak. In contrast, in coated composites, most of fiber is broken (marked as rectangular), as shown in Fig. 16b, suggesting the interfacial bonding was good. The strong interface between $\mathrm{Cu}-\mathrm{Al}$ and $\mathrm{Cu}$-fiber improved the load-bearing capability of $\mathrm{CF} / \mathrm{Al}$ composite at the interface through $\mathrm{Cu}$ nanoparticles. So, the mechanical properties of $\mathrm{CF} / \mathrm{Al}$ composites depend on the interfacial bonding strength and the interaction between matrix and fiber.

\subsection{Wear Rate Measurement}

Figure 17 shows the effect of $\mathrm{CF}$ and the coating process on the specific wear rate of the prepared samples. It revealed that the wear rate decreases gradually by increasing CF percentage, and the coated samples have a lower wear rate than the uncoated ones. It is well known that hard ceramic particles result in improved wear behavior of $\mathrm{AMC}_{\mathrm{S}}$ composites [70, 71]. In our study, the addition of $\mathrm{CF}$ into the $\mathrm{Al}$ matrix was an effective approach to enhance the wear properties of composites. The specific wear rate decreased as the weight fraction of $\mathrm{CF}$ increased, and this correlates to the literature $[72,73]$. CF particles resist the micro-cutting of composites and restrain plastic deformation created by the cyclic load, so the wear rate of composites is decreased. The COF of composites in Fig. 18 follows the same trend, in which the $\mathrm{COF}$ of $\mathrm{CF} / \mathrm{Al}$ composites is lower than the pure $\mathrm{Al}$. $\mathrm{CF}$ usually acts as a self-lubricating film that restricts the direct contact between the sliding surface of composites and the counterpart. The incorporation of $\mathrm{CF}$ in the $\mathrm{Al}$ matrix enhances the wear resistance as CF has a lower density than $\mathrm{Al}$, so it floats on the sample's surfaces, producing tribological layers that resist the wear and friction of samples. Jung et al. [74] stated similar results for $\mathrm{CF} / \mathrm{Al}$ composites and observed that COF decreases as the mass of $\mathrm{CF}$ increases. Coated fiber could increase the load capacity of $\mathrm{CF} / \mathrm{Al}$ composites due to improvement in wettability; thus, the COF and specific wear rate are reduced. The excellent adhesion and bonding between fiber and matrix are essential in systems 

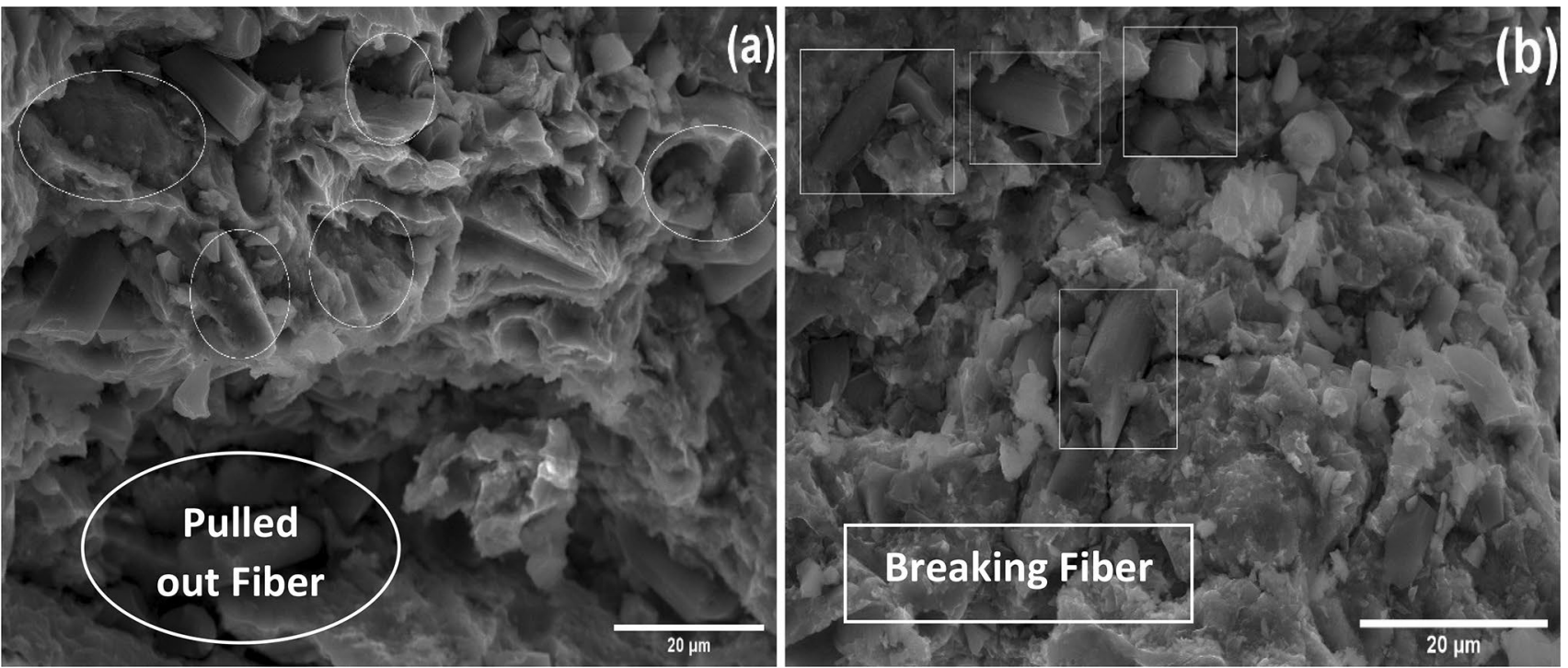

Fig. 16 Fractural microstructure of $20 \mathrm{wt} \% \mathrm{CF}$ a uncoated composite, and $\mathbf{b}$ coated composite

Fig. 17 Specific wear rate of CF/Al composites

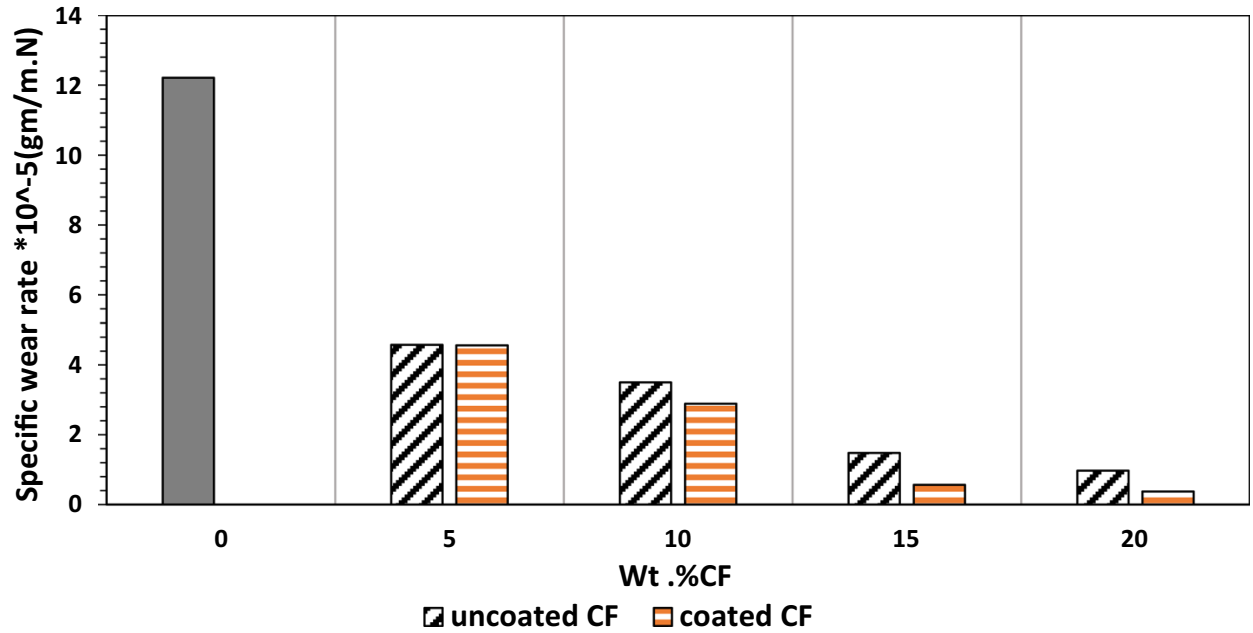

where wear mechanisms occur $[75,76]$. As a general rule, the presence of coating layers on reinforcement displayed a better improvement in the tribological behavior of $\mathrm{CF} / \mathrm{Al}$ composites.

The worn surfaces of unreinforced $\mathrm{Al}$ and composites reinforced with uncoated and coated $\mathrm{CF}$ at $10 \mathrm{wt} \%$ are presented in Fig. 19. The worn surface of the Al sample primarily contains grooves, wedges and microcracks. The delamination wear mechanism causes wedges and deep grooves, while the adhesive wear mechanism causes microcracks [71]. During the wear process, the friction force causes cyclic stresses on both sides of friction surfaces due to an increase in the temperature of the $\mathrm{Al}$ surface. This increase in temperature decreases the toughness and strength of $\mathrm{Al}$, thereby severe plastic deformation occurred, and some Al grains started to peel off, as shown in Fig. 19a. In contrast, the SEM micrograph of the worn surface of uncoated CF / Al composites reveals that longitudinal grooves are shallower and narrower compared to the pure sample. In addition, grain stripping and plastic deformation on the surface are weak. The previous observations indicated that the system turned from a high wear regime to an ultra-mild wear regime due to adding CF. It is also observed that fiber hasn't detached from the matrix and is distributed in a homogenous way in the sliding direction, which improves wear properties of composites, shown as in Fig. 19b. The previous observation is confirmed by the report [77]. Figure 19c shows that coated CF composites had the fewest grooves with some pits observed in the sample, thus coated $\mathrm{CF} / \mathrm{Al}$ composites 


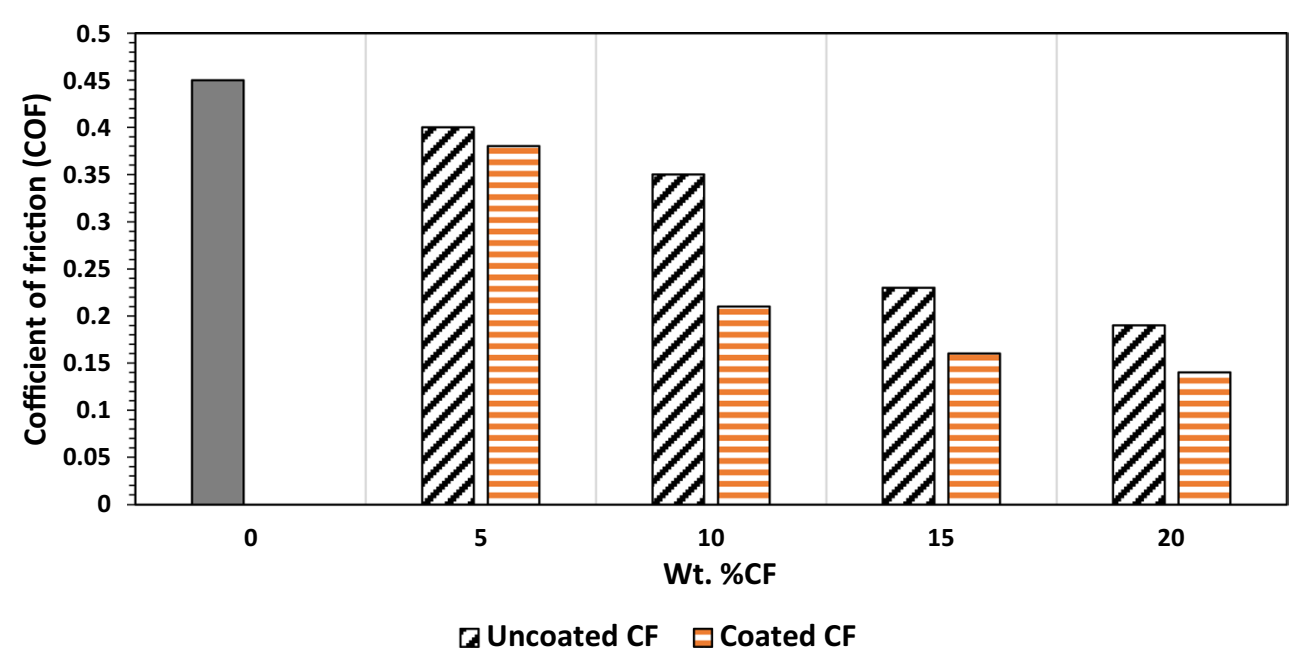

Fig. 18 Coefficient of friction of CF/Al composites
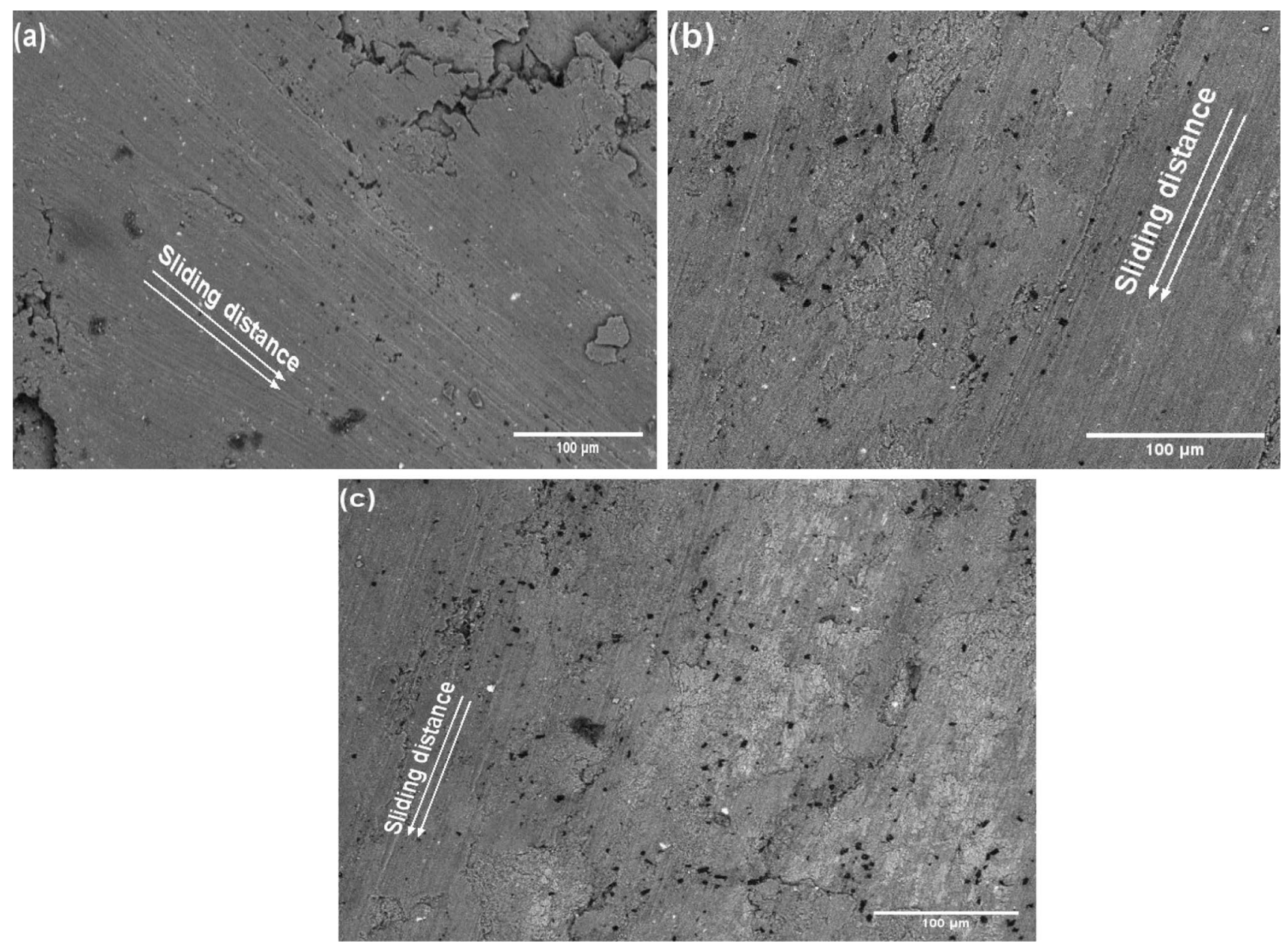

Fig. 19 Worn surfaces of composites tested under $5 \mathrm{~N}$ with $1400 \mathrm{r} / \mathrm{min}$ a Pure Al powders, $\mathbf{b} 10 \mathrm{wt} \% \mathrm{CF} / \mathrm{Al}$ composites, and $\mathbf{c} 10 \mathrm{wt} \% \mathrm{Cu}$-coated $\mathrm{CF} / \mathrm{Al}$ composites 
had a lower wear rate and COF compared to uncoated and pure ones.

\section{Conclusions}

In this study, the authors aimed to solve the challenges of the fabrications of CF/Al composites through surface modification of $\mathrm{CF}$ surfaces by the nano $\mathrm{Cu}$ layer. In this investigation, $0,5,10,15$, and $20 \mathrm{wt} \%$ uncoated and $\mathrm{Cu}-$ coated CF /Al composites were successfully synthesized using the hot coining method. The composites are characterized by studying the microstructure, density, electri$\mathrm{cal}$, thermal and mechanical properties, considering the reinforcement content and electroless $\mathrm{Cu}$ coating process.

The results indicate that $\mathrm{CF}$ particles are uniformly distributed in $\mathrm{Al}$ matrix with some agglomerations in uncoated composites at a higher percentage of reinforcement. Moreover, nano $\mathrm{Cu}$ particles were effectively coated on CF surfaces and distributed between CF particles, contributing to the reduction of agglomerations and enhancing the interfaces between matrix and reinforcement. Also, $\mathrm{XRD}$ analysis of composites indicated that only $\mathrm{Al}$ and $\mathrm{CF}$ peaks were recorded, and also the absence of $\mathrm{Al}_{4} \mathrm{C}_{3}$ in all composites and $\mathrm{Al}_{2} \mathrm{Cu}$ in coated composites. The relative density decreased with an increase in $\mathrm{CF}$ content due to micropores formations.

Increasing the amount of $\mathrm{CF}$ and using the nano $\mathrm{Cu}$ coated reinforcement reduced the CTE of composites. In addition, the electrical and thermal conductivities increased up to $10 \mathrm{wt} \%$ for uncoated CF composites and up to $15 \mathrm{wt} \%$ for coated composites. For uncoated composites, the hardness improved up to $10 \mathrm{wt} \% \mathrm{CF}$, while it continued to increase after $10 \mathrm{wt} \% \mathrm{CF}$ when coated $\mathrm{CF}$ was used as reinforcement. Increasing $\mathrm{CF}$ content from 0 to $20 \mathrm{wt} \%$ caused a reduction in compressive strength for both uncoated and coated samples. The lowest value of compression strength was recorded at $20 \mathrm{wt} \%$ of uncoated $\mathrm{CF} / \mathrm{Al}$ composite. Additionally, the incorporation of $\mathrm{CF}$ enhanced the wear resistance in the $\mathrm{Al}$ matrix, which specific wear rate and COF decreased as the $\mathrm{CF}$ content increased. In general, surface modification of $\mathrm{CF}$ with nano $\mathrm{Cu}$ layer was an effective way to improve the structure and thus, the electrical, thermal and mechanical properties of $\mathrm{CF} / \mathrm{Al}$ composites are enhanced.

Acknowledgements We would like to acknowledge the Central Metallurgical Research and Development Institute (CMRDI) for its support.

Funding Open access funding provided by The Science, Technology \& Innovation Funding Authority (STDF) in cooperation with The Egyptian Knowledge Bank (EKB). This research did not receive any specific grant from funding agencies in the public, commercial, or notfor-profit sectors.

\section{Declarations}

Conflict of interest The authors declare that they have no conflict of interest.

Open Access This article is licensed under a Creative Commons Attribution 4.0 International License, which permits use, sharing, adaptation, distribution and reproduction in any medium or format, as long as you give appropriate credit to the original author(s) and the source, provide a link to the Creative Commons licence, and indicate if changes were made. The images or other third party material in this article are included in the article's Creative Commons licence, unless indicated otherwise in a credit line to the material. If material is not included in the article's Creative Commons licence and your intended use is not permitted by statutory regulation or exceeds the permitted use, you will need to obtain permission directly from the copyright holder. To view a copy of this licence, visit http://creativecommons.org/licenses/by/4.0/.

\section{References}

1. C. Guo, X. He, S. Ren, X. Qu, J. Alloy. Compd. 664, 777 (2016)

2. J. Cho, K.E. Goodson, Nat. Mater. 14, 136 (2015)

3. A. Veillere, J.-M. Heintz, N. Chandra, J. Douin, M. Lahaye, G. Lalet, C. Vincent, J.-F. Silvain, Mater. Res. Bull. 47, 375 (2012)

4. Y. Huang, Q. Ouyang, Q. Guo, X. Guo, G. Zhang, D. Zhang, Mater. Design 90, 508 (2016)

5. W.W. Zhang, Y. Hu, Z. Wang, C. Yang, G.Q. Zhang, K.G. Prashanth, C. Suryanarayana, Mater. Sci. Eng. A 734, 34 (2018)

6. A. Fathy, D. Ibrahim, O. Elkady, M. Hassan, J. Compos. Mater. 53, 209 (2019)

7. R. Pei, G. Chen, Y. Wang, M. Zhao, G. Wu, J. Alloy. Compd. 756, 8 (2018)

8. K. Shirvanimoghaddam, S.U. Hamim, M.K. Akbari, S.M. Fakhrhoseini, H. Khayyam, A.H. Pakseresht, E. Ghasali, M. Zabet, K.S. Munir, S. Jia, P. Davim, M. Naebe, Compos. Part A Appl. Sci. Manuf. 92, 70 (2017)

9. H. Naji, S.M. Zebarjad, S.A. Sajjadi, Mater. Sci. Eng. A 486, 413 (2008)

10. M. Eid, S. Kayetbay, O. Elkady, A. El-Assal, Ceram. Int. 47, 21890 (2021)

11. M. Baghi, B. Niroumand, R. Emadi, J. Alloy. Compd. 710, 29 (2017)

12. E. Hajjari, M. Divandari, A.R. Mirhabibi, Mater. Design 31, 2381 (2010)

13. M.E. Abd EL-Maboud, S.M. Kayetbay, A.M. El-Assal, Am. J. Eng. Res. 10, 134 (2021)

14. D.B. Miracle, Compos. Sci. Technol. 65, 2526 (2005)

15. A. Luedtke, Adv. Eng. Mater. 6, 142 (2004)

16. C. Zweben, Jom 50, 47 (1998)

17. X. Peng, Y. Huang, X. Sun, X. Han, R. Fan, J. Mater. Sci. Mater. Electron. 30, 7226 (2019)

18. S.-I. Oh, J.-Y. Lim, Y.-C. Kim, J. Yoon, G.-H. Kim, J. Lee, Y.-M. Sung, J.-H. Han, J. Alloy. Compd. 542, 111 (2012)

19. X. Cao, Q. Shi, D. Liu, Z. Feng, Q. Liu, G. Chen, Compos. Part B Eng. 139, 97 (2018)

20. Y. Huang, Q. Ouyang, D. Zhang, J. Zhu, R. Li, H. Yu, Acta Metall. Sin. Engl. 27, 775 (2014) 
21. Y. Tang, L. Liu, W. Li, B. Shen, W. Hu, Appl. Surf. Sci. 255, 4393 (2009)

22. L.-F. Yi, T. Yamamoto, T. Onda, Z.-C. Chen, J. Compos. Mater. 54, 2539 (2020)

23. S. Ghosh, Thin Solid Films 669, 641 (2019)

24. J. Sudagar, J. Lian, W. Sha, J. Alloy. Compd. 571, 183 (2013)

25. Y. Xue, W. Chen, Q. Zhao, Y. Fu, Surf. Coat. Tech. 358, 409 (2019)

26. Y. Huang, X. Peng, Y. Yang, H. Wu, X. Sun, X. Han, Met. Mater. Int. 24, 1172 (2018)

27. X. Peng, Y. Huang, X. Han, R. Fan, X. liu J. Alloy. Compd. 822, $153584(2020)$

28. M. Eid, S. Kayetbay, O. Elkady, A. El-Assal, Int. J. Sci. Tech. Res. 10, $122(2021)$

29. D. Jiang, X. Zhu, J. Yu, J. Wuhan Univ. Technol. 35, 9 (2020)

30. Y. Huang, Y. Su, X. Guo, Q. Guo, Q. Ouyang, G. Zhang, D. Zhang, J. Alloy. Compd. 711, 22 (2017)

31. M. Lee, Y. Choi, K. Sugio, K. Matsugi, G. Sasaki, Compos. Sci. Technol. 97, 1 (2014)

32. T. Etter, P. Schulz, M. Weber, J. Metz, M. Wimmler, J.F. Löffler, P.J. Uggowitzer, Mater. Sci. Eng. A 448, 1 (2007)

33. C. Zhang, Z. Cai, R. Wang, C. Peng, K. Qiu, N. Wang, Mater. Design 95, 39 (2016)

34. N. Panwar, A. Chauhan, Mater. Today Proc. 5, 5933 (2018)

35. S. Tahamtan, A. Halvaee, M. Emamy, M.S. Zabihi, Mater. Design 49, 347 (2013)

36. J. Xiong, H. Zhang, Y. Peng, J. Li, F. Zhang, J. Therm. Spray Techn. 27, 727 (2018)

37. O. El-Kady, A. Fathy, Mater. Design 54, 348 (2014)

38. Z. Cai, C. Zhang, R. Wang, C. Peng, K. Qiu, Y. Feng, Mater. Design 87, 996 (2015)

39. J. Rams, A. Urena, M.D. Escalera, M. Sanchez, Compos. Part A Appl. Sci. Manuf. 38, 566 (2007)

40. M. Deshpande, R. Waikar, R. Gondil, S.V.S.N. Murty, T.S. Mahata, Processing of carbon fiber reinforced aluminium (7075) metal matrix composite, in International Conference On Renewable Energy And Materials For Sustainability (ICREMS) 2016, Noorul Islam Centre for Higher Education, Nagerkoil, 20-21 October 2016

41. A. Urena, J. Rams, M.D. Escalera, M. Sanchez, Compos. Sci. Technol. 65, 2025 (2005)

42. A. Urena, J. Rams, M. Campo, M. Sanchez, Wear 266, 1128 (2009)

43. ASTM B962-08, Standard Test Methods for Density of Compacted or Sintered Powder Metallurgy (PM) Products Using Archimedes' Principle (ASTM International, West Conshohocken, 2008)

44. A. Fathy, O. El-Kady, Mater. Design 46, 355 (2013)

45. A. Fathy, F. Shehata, M. Abdelhameed, M. Elmahdy, Mater. Design 36, 100 (2012)

46. W.S. Barakat, A. Wagih, O.A. Elkady, A. Abu-Oqail, A. Fathy, A. El-Nikhaily, Compos. Part B Eng. 175, 107140 (2019)

47. Y. Li, R. Tian, Y. Xiao, W. Wang, X. Ding, L. Yin, J. Zhang, Mol. Cryst. Liq. Cryst. 651, 273 (2017)

48. M.J. Yu, X.L. Cai, L. Zhou, C. Hu, Z. Li, F. Yi, Key Eng. Mater. 609-610, 394 (2014)

49. M. Islam, M.R. Azhar, N. Fredj, T.D. Burleigh, O.R. Oloyede, A.A. Almajid, S.I. Shah, Surf. Coat. Tech. 261, 141 (2015)
50. H. Xu, Z. Yang, M.-K. Li, Y.-L. Shi, Y. Huang, H.-L. Li, Surf. Coat. Tech. 191, 161 (2005)

51. A. Fathy, O. Elkady, A. Abu-Oqail, Mater. Sci. Technol. 33, 2138 (2017)

52. Y. Jia, F. Cao, S. Scudino, P. Ma, H. Li, L. Yu, J. Eckert, J. Sun, Mater. Design 57, 585 (2014)

53. P.S. Turner, The Problem of Thermal-Expansion Stresses in Reinforced Plastics (National Advisory Committee for Aeronautics, United States, 1942)

54. Y. Zhang, G. Wu, T. Nonferr. Metal. Soc. 20, 2148 (2010)

55. I. Momohjimoh, N. Saheb, M.A. Hussein, T. Laoui, N. Al-Aqeeli, Ceram. Int. 46, 16008 (2020)

56. O.A.M. Elkady, A. Abu-Oqail, E.M.M. Ewais, M. El-Sheikh, J. Alloy. Compd. 625, 309 (2015)

57. O. El-Kady, H.M. Yehia, F. Nouh, Int. J. Refract. Met. Hard Mater. 79, 108 (2019)

58. S.E. Shin, H.J. Choi, D. Bae, J. Compos. Mater. 47, 2249 (2013)

59. T. Liu, X. He, L. Zhang, Q. Liu, X. Qu, J. Compos. Mater. 48, 2207 (2014)

60. L.G. Hou, R.Z. Wu, X.D. Wang, J.H. Zhang, M.L. Zhang, A.P. Dong, B.D. Sun, J. Alloy. Compd. 695, 2820 (2017)

61. G.E. Dieter, D.J. Bacon, Mechanical Metallurgy (McGraw-hill New York, 1988)

62. B.B. Singh, M. Balasubramanian, J. Mater. Process. Tech. 209, 2104 (2009)

63. M.M.E.-S. Seleman, M.M.Z. Ahmed, S. Ataya, J. Mater. Sci. Technol. 34, 1580 (2018)

64. F. Mokdad, D.L. Chen, Z.Y. Liu, D.R. Ni, B.L. Xiao, Z.Y. Ma, Mater. Sci. Eng. A 695, 322 (2017)

65. M. Deshpande, R. Gondil, S.V.S.N. Murty, R.K. Kalal, T. Indian I. Metals 71, 993 (2018)

66. Z. Hu, X. Li, H. Yan, X. Wu, H. Qun, J. Lin, J. Alloy. Compd. 685, $58(2016)$

67. O.V. Rofman, A.V. Mikhaylovskaya, A.D. Kotov, A.G. Mochugovskiy, A.K. Mohamed, V.V. Cheverikin, M.P. Short, Mater. Sci. Eng. A 790, 139697 (2020)

68. J. Segurado, C. Gonzalez, J. Llorca, Acta Mater. 51, 2355 (2003)

69. S. Pourhosseini, H. Beygi, S.A. Sajjadi, Mater. Sci. Technol. 34, 145 (2018)

70. A. Fathy, A. Abu-Oqail, A. Wagih, Ceram. Int. 44, 22135 (2018)

71. N. Idusuyi, J.I. Olayinka, J. Mater. Res. Technol. 8, 3338 (2019)

72. X.-L. Kong, Y. Liu, Y. Lu, B. Yang, Investigation of friction and wear behavior of carbon fiber felt reinforced aluminum-matrix composites. Tribology(China) 21, 448 (2001)

73. L. Liu, W. Li, Y. Tang, B. Shen, W. Hu, Wear 266, 733 (2009)

74. K.H. Jung, S. Nam, S.-S. Kang, B.-C. Ku, Y.H. Bang, J.Y. Hwang, Carbon Lett. 21, 103 (2017)

75. S. Wilson, A.T. Alpas, Wear 225-229, 440 (1999)

76. S.F. Moustafa, S.A. El-Badry, A.M. Sanad, B. Kieback, Wear 253, 699 (2002)

77. Y.Q. Wang, J.I. Song, Wear 270, 499 (2011)

Publisher's Note Springer Nature remains neutral with regard to jurisdictional claims in published maps and institutional affiliations. 